\title{
The Issue of Groundwater Salinization in Coastal Areas of the Mediterranean Region: A Review
}

\author{
Micòl Mastrocicco ${ }^{1}(\mathbb{D})$ and Nicolò Colombani ${ }^{2, *(\mathbb{D})}$ \\ 1 Department of Environmental, Biological and Pharmaceutical Sciences and Technologies, \\ Campania University "Vanvitelli", 81100 Caserta, Italy; micol.mastrocicco@unicampania.it \\ 2 Department of Materials, Environmental Sciences and Urban Planning, Polytechnic University of Marche, \\ 60131 Ancona, Italy \\ * Correspondence: n.colombani@univpm.it; Tel.: +39-071-220-4710
}

Citation: Mastrocicco, M.; Colombani,

N. The Issue of Groundwater Salinization in Coastal Areas of the Mediterranean Region: A Review. Water 2021, 13, 90. https://doi.org/ 10.3390/w13010090

Received: 29 October 2020 Accepted: 30 December 2020 Published: 4 January 2021

Publisher's Note: MDPI stays neutral with regard to jurisdictional clai$\mathrm{ms}$ in published maps and institutional affiliations.

Copyright: (C) 2021 by the authors. Licensee MDPI, Basel, Switzerland. This article is an open access article distributed under the terms and conditions of the Creative Commons Attribution (CC BY) license (https:// creativecommons.org/licenses/by/ $4.0 /)$.

\begin{abstract}
The Mediterranean area is undergoing intensive demographic, social, cultural, economic, and environmental changes. This generates multiple environmental pressures such as increased demand for water resources, generation of pollution related to wastewater discharge, and land consumption. In the Mediterranean area, recent climate change studies forecast large impacts on the hydrologic cycle. Thus, in the next years, surface and ground-water resources will be gradually more stressed, especially in coastal areas. In this review paper, the historical and geographical distribution of peer-review studies and the main mechanisms that promote aquifer salinization in the Mediterranean area are critically discussed, providing the state of the art on topics such as actual saltwater wedge characterization, paleo-salinities in coastal areas, water-rock interactions, geophysical techniques aimed at delineating the areal and vertical extent of saltwater intrusion, management of groundwater overexploitation using numerical models and GIS mapping techniques for aquifer vulnerability to salinization. Each of the above-mentioned approaches has potential advantages and drawbacks; thus, the best tactic to tackle coastal aquifer management is to employ a combination of approaches. Finally, the number of studies focusing on predictions of climate change effects on coastal aquifers are growing but are still very limited and surely need further research.
\end{abstract}

Keywords: coastal aquifer; climate change impacts; characterization methods; salinization origin; prediction scenarios

\section{Introduction}

The climate has changed in the past, is changing now, and will change in the future. The main concern raised by climate change (CC) is that it alters the global hydrological cycle (GHC) around the world, even under the most stringent emissions mitigation scenarios [1-3]. To date, most research has been conducted on the above ground components of the GHC, both on historical and projected changes [4,5]. Conversely, for the sub-surface components of the GHC, the picture is still fragmentary [6,7]. In the next years, arid and semi-arid lands are forecast to become the largest terrestrial biome on Earth [8,9] with a progressive loss of surface water (SW) resources due to contamination and increasing demand for intensive agriculture and demographic and economic growth. Consequently, groundwater (GW) resources will be gradually more stressed, with the likely result of accelerating GW depletion both quantitatively and qualitatively. These impacts will especially hit coastal areas where large socio-economic and environmental stresses are already acting and will rise due to CC [10]. More specifically, these effects will be emphasized in the semi-arid zones and delta areas along which many human activities are concentrated and where sustainable water resources management is essential for ensuring the integration of social, economic, and environmental issues [11].

One of the most widespread and alarming phenomena affecting coastal areas is the progressive salinization of water resources, from both natural and anthropogenic 
sources [12]. The increasing demand of freshwater, already registered and expect to increase due to CC and the consequent land use changes, has intensified the research on GW salinization, as GW has gained increasing attention as a source of water supply owing to its relatively low vulnerability to pollution in comparison to SW, and its large storage capacity [12]. Even though some comprehensive reviews focusing on the definition, recognition, and monitoring strategies of seawater intrusion (SWI) were already available at the end of the 1990s [13,14], it is above all in the last decade that research on this topic has made enormous strides by deepening not only the understanding of the mechanisms that govern salinization processes [15-18] but also investigating the effects of salinization of water resources on the surrounding environment $[19,20]$ and recognizing its interaction with human activities [21], thus defining possible adaptive measures and solutions to deal with the actual issues and to face future scenarios [22,23]. In particular, these last studies have emphasized that in the absence of a sustainable water resources management, uncontrolled land-use activities and over exploitation can lead to a relevant and long-lasting deterioration of coastal water resources and ecosystems. Thus, long-term monitoring schemes are needed to detect and understand climate-related spatiotemporal trends in groundwater quality. However, understanding the interactions between the coastal zone and global changes cannot be achieved by observational studies alone. Modelling of key environmental processes is a vital tool that must be used if coastal management has to achieve its overall goal of protecting natural resources (soil, water, and biodiversity) [24].

\section{A Snapshot in the Mediterranean Basin}

In the light of what has been said so far, it is considered superfluous to carry out an extensive methodological review on the techniques for characterizing freshwater/saltwater interaction both in laboratory and field conditions in terms of identifying the various sources of salinization (natural and anthropic), the various hydrogeological and geochemical mechanisms involved, the impacts on the environment and human activities, the vast processing approaches used to handle data, and the many solutions proposed to mitigate the phenomenon of GW salinization. For all these aspects, the authors refer the reader to the comprehensive and recent reviews cited in the introduction.

The main purpose of this work is to provide the reader with a snapshot on the issue of the salinization of GW resources in the Mediterranean basin, which is considered a hot spot for $\mathrm{CC}$, and to elucidate the various approaches so far employed to disentangle various sources of salinization in coastal aquifers of this area. The Mediterranean region has shown large climate shifts in the past [25], and evidence from model projections indicates that the Mediterranean might be one of the most significant "Hot-Spots" in future CC [26,27]. In the Mediterranean region, recent studies forecast an increase in temperature, especially in summer [28], a probable decrease in precipitation and a change in the in-year precipitation pattern $[28,29]$. This, along with the potential of pronounced sea level rise under global warming [30,31], could have devastating effects on water resources, natural ecosystems (both terrestrial and marine), human activities (e.g., agriculture, recreation, tourism), and health. About 450 million people live along the $46,000 \mathrm{~km}$ of the Mediterranean basin, belonging to as many as 20 different nationalities, and are concentrated above all in the fertile coastal plains, where the density of inhabitants can reach up to $1300 \mathrm{in} / \mathrm{km}^{2}$. This strong demographic pressure, which is also expected to rapidly increase, especially along the coasts in the next decade, places evident stresses on both SW and GW resources. Moreover, in the Mediterranean, the GW resources are not distributed in a homogeneous fashion both at a regional scale and within each country. Thus, the increase in GW exploitation poses a severe risk for the availability of water resources, and the resulting scarcity is a major concern in most countries of the Mediterranean region [32]. If the lack of resources is compounded by the qualitative impact on GW resources induced by CC, the prospects can be troubling. This vision is exemplified by the following discussion, which highlights how the approach to the issue of GW salinization has prompted many Mediterranean countries to intensify their efforts not only to characterize and understand the processes in place but 
above all, in recent years, to the definition of strategies that allow minimizing their effects in the near future.

\section{Materials and Methods}

This work takes into consideration 304 studies focusing on the salinization issue along the Mediterranean coastline (Figure 1). In order to select the studies considered in this work, we conducted a search in the Scopus database (Elsevier) was conducted using various combinations of the following keywords to perform the research: groundwater; salinization; seawater; coastal aquifer; saltwater wedge. The search was repeated for each country using the "affiliation country" as an additional search term. Moreover, to spatially cover the whole Mediterranean area, we performed a selection of the papers to be explicitly cited by this review, following the criteria of both journal ranking (excluding low ranked journals) and number of citations where a high density of studies was available. No time limits were attributed to the search, while from a spatial point of view, only studies at a maximum distance from the coast of about $100 \mathrm{~km}$ were considered. Apart from the peer review papers in the Scopus database, it must be acknowledged that the most important conference on this topic is The Salt Water Intrusion Meetings (SWIMs), which have been held since 1968 every two years. From 2000, also the Salt Water Intrusion in Coastal Aquifers (SWICA) was also added to SWIM and formed an initiative to address salt water intrusion at the global scale. Given the large number of studies in this area, only the contributions published in peer-reviewed international journals were retained for the data analysis. The studies were distinguished into three main categories: (i) methodological studies in which new techniques have been proposed; (ii) studies on the origins and mechanisms of aquifer salinization where the main objective was to discover and quantify the main sources of aquifer salinization; and (iii) predictive studies on the possible evolution of groundwater quality in coastal aquifer due to different stresses. It must be pointed out that the categorization was performed with the simple aim of constructing a logic pathway to analyze the literature in this specific field, but since this choice is inherently subjective, a large overlap is possible between categories.

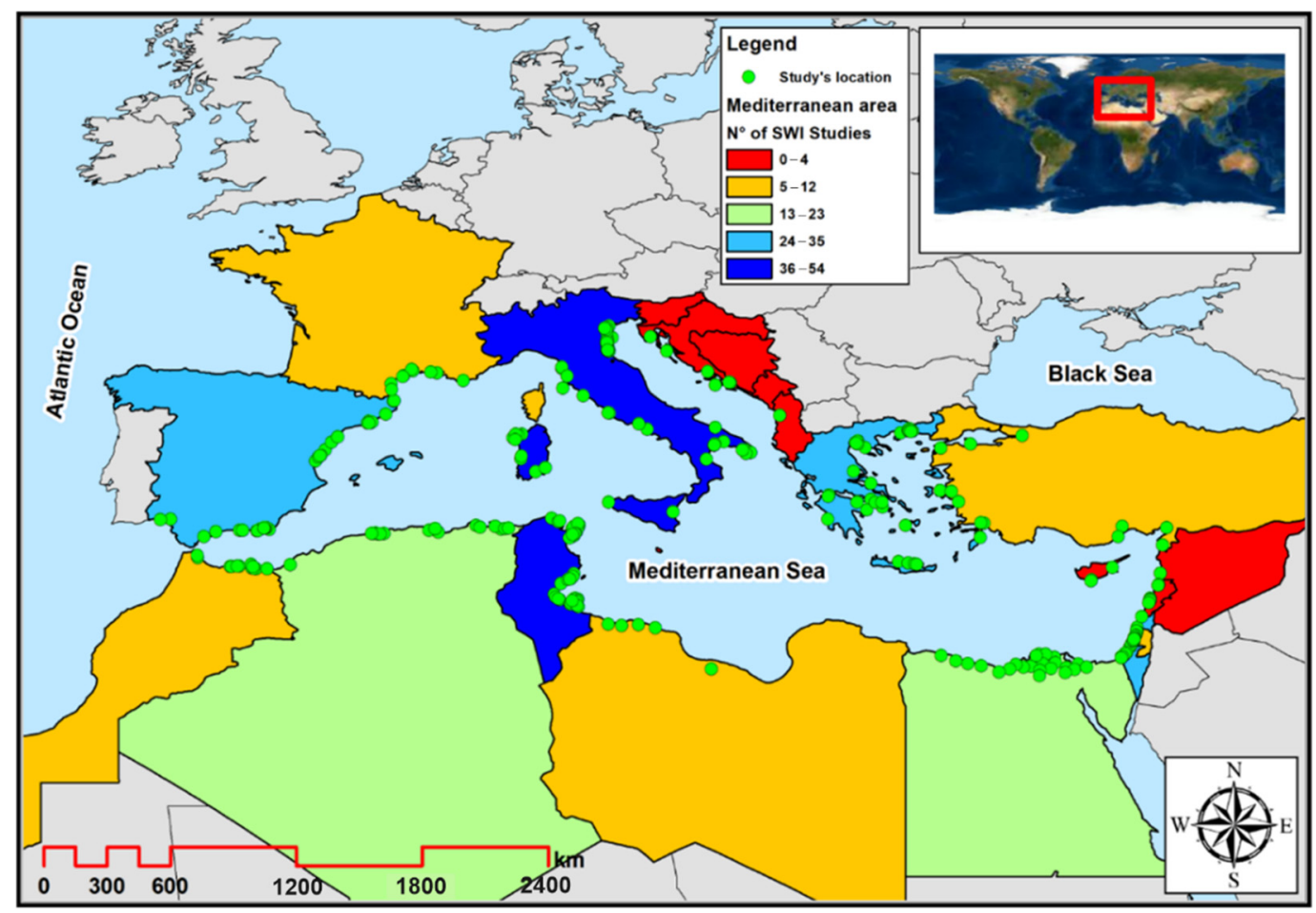

Figure 1. Distribution of the studies focusing on groundwater (GW) salinization along the Mediterranean coast. 


\section{Results and Discussion}

\subsection{Spatio-Temporal Distribution of the Studies}

The 304 studies analyzed are spread over a period of 35 years, from 1985 to present (Figure 2, left panel). Up to 2005, no more than 10 contributions per year were ever exceeded, and afterwards the number of studies per year increased up to 32 studies in 2017. In general, the number of studies increased from 2013 onward, due to the greater availability of economic resources made available by public and private bodies to tackle the increasingly pressing problem of GW salinization. The countries that have contributed most to the publication of studies on GW salinization are Italy, Tunisia, Greece, Spain, and Israel (Figure 2, right panel), but even for them, the temporal trend is completely different from country to country. In fact, while Israel, Spain, and Greece show a linear increase in studies starting from the 1990s, for Italy and Tunisia, the increase in recent years is much more marked and the first studies on the subject date back only to 2000. The increase is particularly evident after 2010, the year in which the number of studies that acknowledge a funding entity in the Scopus database is nearly doubled.
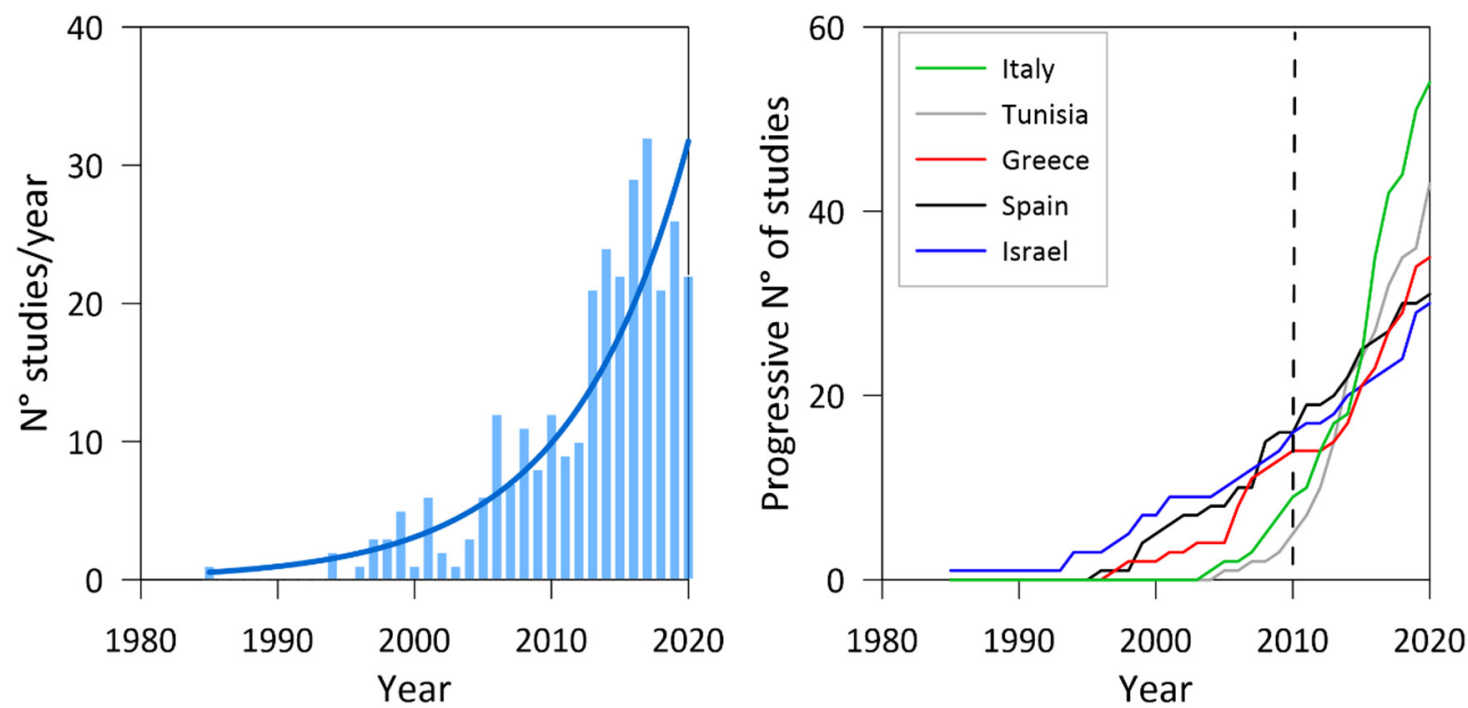

Figure 2. Studies focusing on GW salinization from 1980 to present for all the Mediterranean countries (left panel) with the blue line showing their exponential growth, and trend for the most productive countries over the same period (right panel) with the dashed black line indicating the year in which the number of studies that acknowledge a funding entity is nearly doubled.

An interesting subdivision of the published studies can be deduced if the coastal extension of each country bordering the Mediterranean basin is taken into consideration (Figure 3). In this case it is evident that the contribution of the countries of the southern Mediterranean shore is much more intense, with Palestine showing the highest number of works published every $100 \mathrm{~km}$ of coastline. Since the graph is in logarithmic scale, the following countries can be grouped together starting from: (i) Palestine and Israel; (ii) Tunisia, Lebanon, Egypt, Morocco, Spain, Algeria, and France; (iii) Italy, Syria, Turkey, Cyprus; (iv) Libya Albania, Greece and Croatia have much less studies respect to their coastal extension. This emphasizes a greater interest in the problem of GW salinization precisely in countries where the issues relating to water scarcity are yet more pressing. An exception is Greece, even if is highly affected by water scarcity, since its coastal extension is huge with respect to its area. While Libya and Syria have low values despite their extremely high water scarcity because military conflicts have played a role. 


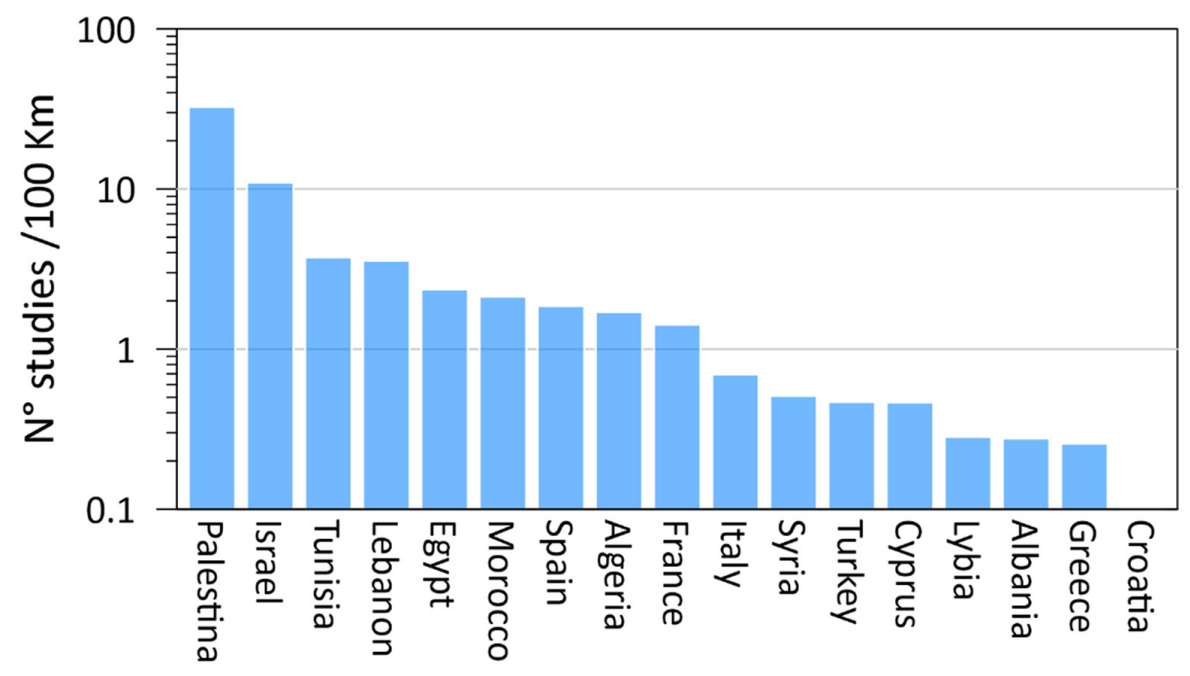

Figure 3. Number of studies focusing on GW salinization with respect to the coastal extension of each country along the Mediterranean.

As regards the extension of the studies focusing on GW salinization in the Mediterranean, the vast majority have an extension between $10^{2}$ and $10^{3} \mathrm{Km}^{2}$ (Figure 4a); a fair number of studies have been carried out on more limited areas, extended between 10 and $10^{2} \mathrm{~km}^{2}$, while regional studies are far more scarce. Only very few studies on the entire Nile delta cover an area greater than $10^{6} \mathrm{~km}^{2}$, while some studies in Egypt, Israel, and Tunisia cover areas between $10^{4}$ and $10^{5} \mathrm{~km}^{2}$. The scarcity of studies at the regional level does not only depend on the frequent need to solve specific local problems that increase the number of pilot and small-scale studies, but also, and perhaps above all, on the lack of extensive and homogeneous monitoring networks that can allow a consistent characterization of a large portion of the coast.
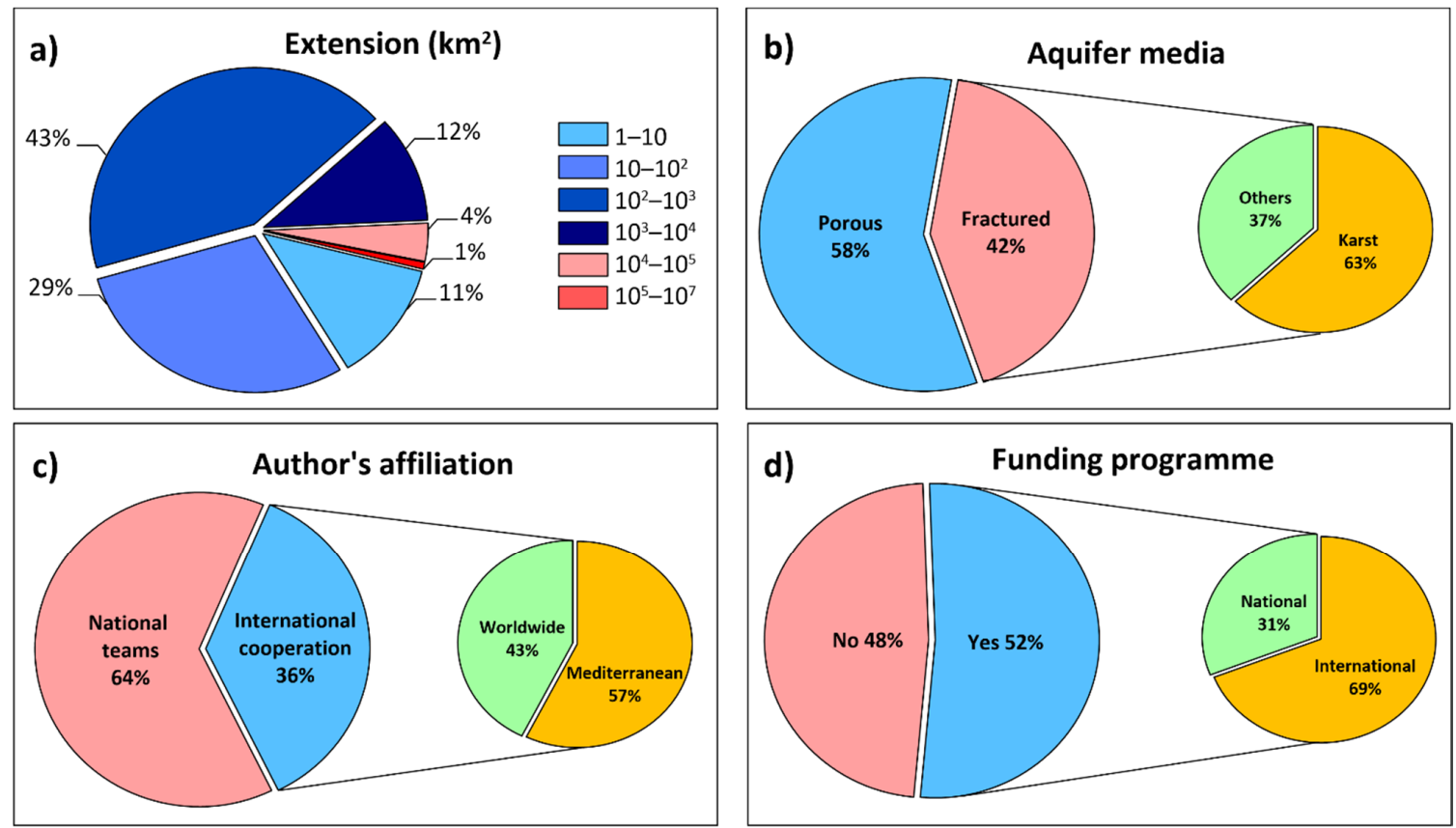

Figure 4. Geographical extension (a) and type of aquifer (b) of the studies focusing on GW salinization; relevance of international cooperation (c) and funding programmes (d) within the selected studies. 
Considering the type of aquifer investigated, Figure $4 \mathrm{~b}$ shows that there is a slight prevalence of studies on porous aquifers compared to those on fractured aquifers. In the porous aquifers, the largest number of studies concerns the main deltas of the Mediterranean (Nile, Po, Rhône, Ebro, and Llobregat), while in the fractured aquifers, most of the studies investigate karst aquifers, especially along the southeastern coast of the Mediterranean basin. In this case, it is believed that the smaller number of studies on karst massifs with respect to the alluvial aquifers - even though karst massifs are among the largest GW reserves on earth-is due to the technical difficulties and high costs that characterize the field activities.

One aspect that is worth investigating is the weight of international collaborations in the studies considered and the availability of funds. As can be seen from Figure 4c, most of the studies on GW salinization have been conducted by national teams, and only a third of the studies involve international collaborations, most of which involve neighboring countries, or at least countries belonging to the Mediterranean area. As regards the availability of funds to conduct the research (Figure 4d), in general, about half of the studies report some type of funding (mostly from international bodies). However, it should be specified that the distribution of funds is not homogeneous neither from a geographical point of view (with the Balkan countries and Greece behind other countries), nor from a temporal point of view; in fact, starting from 2010, there has been a very strong increase in the availability of funds, which has contributed to boost the research on this topic (see also Figure 2, right panel), together with the intensification of the issues related to water resources deterioration and to the recurrent droughts experienced in the Mediterranean countries.

\subsection{Detailed Analysis of the Topics Covered in the Studies}

The results have been summarized in three main categories in which the studies developed in the Mediterranean area have been subdivided, namely, methodological studies, origin and mechanisms studies on aquifer salinization, and predictive studies (Figure 5).

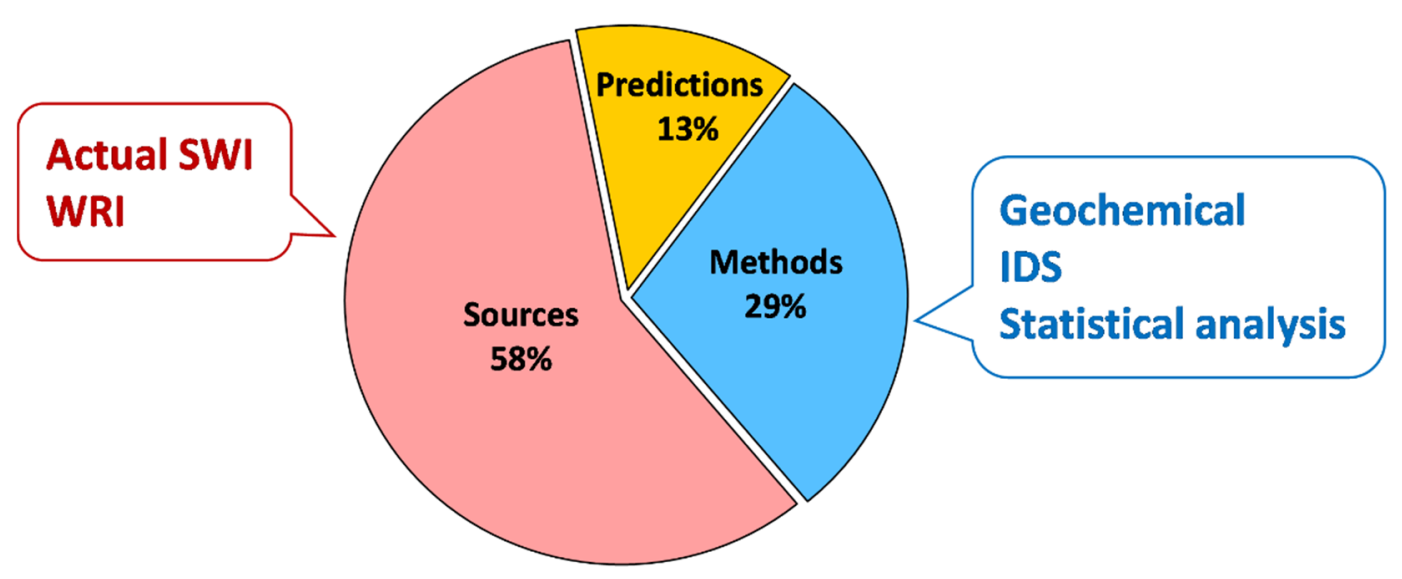

Figure 5. Main topics covered by the studies focusing on GW salinization along the Mediterranean coast. The most common methodologies applied in data acquisition and handling are reported in the blue call out while the most common sources of GW salinization are reported in the red call out.

\subsubsection{Methodological Approaches for Groundwater Salinization Delineation Data Acquisition Techniques}

Many studies have used indirect techniques to monitor the spatial extent of saline groundwater in coastal aquifers, such as geophysical methods. For example, the electrical resistivity tomography (ERT) and geological data have been largely used [33-36] to map zones characterized by high salinities, while ERT coupled with hydrochemical data was less 
commonly employed [37-43], although it provides more robust information in comparison to former. Moreover, the time domain electromagnetic method (TDEM) has been widely employed as a characterization method to delineate the salinization of coastal aquifers with good results at large-scale areas [44-48], while only an example of airborne electromagnetics methods (AEM) has been present [49] due to the high cost of instrumentation and survey. Finally, a new downhole probe subsurface monitoring device (SMD) has been developed to monitor in real time the resistivity variations along a monitoring well profile via a cable loaded with electrodes [50] or via coupled fiber optics and ERT techniques [51].

Moving to field-based monitoring strategies where a direct acquisition of GW samples in the field is planned, was can see that in the vast majority of cases, the acquisition of the GW sample is carried out in pre-existing wells, which were not explicitly designed for research purposes, and by means of standard integrated depth sampling (IDS). On the other hand, the studies carried out via dedicated multi-level samplers (MLSs) to determine the heads and groundwater quality variations induced by saltwater intrusion [52] or to quantify the salinization impact of pumping wells used to feed desalination plants [53] are far less numerous. In all the cases, the use of MLSs enabled the clear recognition of the transition zone variations due to change in vertical shift of the fresh-saline interface and to clearly identify the different sources of salinity that could be present in coastal environments and that are hardly identifiable by using standard integrated depth borehole data $[54,55]$. In fact, the key issue to understand salinization processes and to properly manage groundwater resources is to correctly characterize the vertical variability of groundwater quality. An inexpensive and fast method to obtain depth dependent groundwater quality data is the open borehole logging. Despite the apparent simplicity, the open borehole logging technique has some limitations, especially in coastal zones where the measured values (salinity or any other water property) may be representative of the stratified water column accumulated in the piezometer but not of the processes occurring within the porous media [56]. Mastrocicco et al. [57] have shown that the use of open borehole logging may lead to substantial bias when geochemical interaction between groundwater and sediments are studied or when wide tidal variations are present [56]. On the contrary, MLSs are routinely applied in contaminated sites to map contaminant spreading and to quantify biogeochemical reaction pathways, but less frequently in monitoring the saltwater intrusion in coastal areas because of their high installation and monitoring costs [33,54].

\section{Analytical Techniques}

One of the first papers using major ions and trace elements for a geochemical assessment of GW salinization in the Mediterranean area is the paper by Mercado [58] that analyzed the chromatographic effect of Israel coastal aquifers during salinization and freshening due to their cation exchange capacity as a preliminary tool to delineate whether the aquifer is salinizing or freshening. A decade later, another simple approach was proposed by Melloul and Azmon [59], where groundwater quality trends of selected species were proposed as a qualitative indicator of aquifer salinization and aquifer pollution by anthropogenic sources. More recently, several papers have focused on the origin and distribution of GW salinization either in porous aquifers [60-66], especially in arid and semiarid regions of the Mediterranean basin [67-73], or in fractured aquifers [74-79], by means of a detailed geochemical study. Together with major ions trend, selected trace elements were used to better characterize GW flow and thus salt transport [80].

To further increase the potential in distinguishing the various processes of GW salinization, researchers also employed different major ions ratios were also employed [13,81]. One of the first studies dated back to 1994 [82], in which major ions ratios were used to infer the influence of groundwater overexploitation in the increased aquifer salinization due to actual seawater encroachment. With similar approaches, there are a large number of studies even in recent years that identified actual SWI as the major salinization mechanism [83-91].

Together with the ion ratios approach, a widely used techniques to disentangle the origin of GW salinization is the employment of environmental isotopes. Early studies in 
the Mediterranean area were developed in Israel [92,93], while since the year 2005, there has been a growing legacy of studies employing these techniques. Most of the studies used stable isotopes to distinguish between different GW origins [94-113], while some of them used radioactive isotopes to determine the residence time of GW [114-116], that is, one of the very few pieces of information allowing researchers to distinguish between actual and paleo SWI. These last elements have also been used to study surface water/groundwater interaction; for example, in a recent paper from Mayer et al. [117], short-lived radioactive isotopes, such as radon-222, allowed not only for the determination of the amount of exchange between different water bodies, but also for the ability to precisely derive GW flow velocities and saturated hydraulic conductivities, which are vital parameters to constrain numerical simulations.

\section{Data Handling Techniques}

A widely applied approach to evaluate GW salinization, is surely the one that employed geostatistical methodologies such as multivariate statistical analysis [118-126]. In a recent study, Slama and Bouhlila have strengthened this approach by adding hydrogeochemical modelling to further constrain seawater-freshwater mixing [127].

Other interesting methods consist of using drought indices to qualitatively infer the aquifer salinization trend [128] or using simplified risk assessment methods and fuzzy cognitive maps from the farmer perspective to analyze the impact of agricultural activities on aquifer salinization [129].

Another cluster of papers pertaining to this group tackled the saltwater intrusion delineation by using GIS weighting and rating methods, in which simple overlay maps methods are employed to estimate the vulnerability of a given coastal aquifer to salinization such as the GALDIT method (GALDIT is the acronym formed from the highlighted letters of the parameters used) [130-135], even with modifications to account for surfacegroundwater interactions [136], or by using GIS and water quality index interpolation methods to propose maps of vulnerability to salinization [137-143]. The main advantage of these methods is the relative easiness to handle high amount of data (i.e., spatially continuous precipitation and evapotranspiration data, land use maps, etc.), although GIS weighting and rating methods are often highly user dependent and thus more subjective than numerical models. This because the attribution of the different classes of the rating method is selected by the user and may vary considerably among different users; moreover, the GIS weighting and rating methods are usually static, while numerical models account for the temporal evolution of the aquifer salinization [15].

A more complex and data requiring approach is the one that make use of numerical models to deploy new characterization methods, for example, describing the linear and non-linear optimization approaches to manage seawater intrusion via numerical scenarios [144-150], or determining the long-term effects induced by pumping saline groundwater to feed desalination plants [151]. In addition, the employment of geophysical methods coupled with numerical models to quantify the aquifer salinization extension has been explored only in few studies [152-155], and only one reported the socio-economic aspects of SWI in the modeling procedure [156]. Finally, two studies have employed complex reactive transport models to quantify biogeochemical reactions induced by SWI [157-159]. Besides the physically based density dependent numerical models that need a large number of field data to be calibrated, there has recently been a growing number of papers that have employed the surrogate models, such as non-linear regressive techniques, to describe the SWI phenomenon [160-164], or using simple spreadsheet macros to plot the hydrochemical facies evolution [165]. In general, numerical models have been widely used to quantify the different origins of salinization via density dependent flow and transport models [166-175]. Finally, only a few papers have been conducted involving the coupling major ions, isotope data, or geophysical investigations to achieve a multidisciplinary model construction $[176,177]$. 
From the analysis of the previously mentioned literature, we have been found that the number of studies employing numerical models that account for the effects of fluid density on groundwater flow have been steadily increasing in the last decade. Since such numerical models are specifically suited to address scientific, engineering, and water resource management problems in coastal aquifer where a unique combination of factors (mixed irrigation/drainage canal networks, tidal fluctuations, coastal wetlands, lagoons, etc.) leads to complicated hydrodynamic conditions. However, three-dimensional modelling is usually computationally time consuming when multi species variable density flow and transport problems are simulated. In addition, the field data required for the implementation and calibration of three-dimensional variable density models are usually more complex than the ones needed for simple flow models, and thus their use is actually still limited with respect to classical hydrogeochemical studies.

\subsubsection{Groundwater Salinization Origins and Mechanisms}

The studies that have addressed the salinization origins and their mechanisms in the Mediterranean area are the largest group of papers published in peer-reviewed journals. A large sub-group is constituted by papers that recognize the actual SWI as major salinization mechanism [178-185]; these papers usually employed major ions and trace element geochemical characterizations.

A large number of studies have established that the main source of salinity is coming from water-rock interactions [186-189], and to better establish such relationships in those papers, the researchers largely used stable and radioactive isotopes in groundwater were largely used. Less studies have pointed out paleo-seawaters as the main mechanism of aquifer salinization [190-199], although in many cases this distinction was possible by using high resolution MLSs. Only a few papers distinguished as the main salinization mechanism the return flow from agricultural lands [200-202]. Again, only two papers recognized the geothermal sources as the main salinization mechanism in coastal aquifers [203,204]. Finally, some studies encompass the recognition of multiple sources of salinity such as geothermal fluids, actual and paleo-seawaters, evaporitic rocks dissolution, and anthropogenic sources [205-210]. It is worth remembering here that these latter processes are much more relevant in inland areas.

Another point that can be stressed from the reported literature, is that there is a net prevalence of the spatial analyses [211-216], with respect to the temporal trend analyses [217-223]. This is due to the fact that it is much more challenging to obtain consistent hydrochemical information for long time periods, because the monitoring network must have been sampled and analyzed for the major and minor water constituents without important gaps.

\subsubsection{Predictive Studies of Coastal Aquifers' Salinization}

The studies that have addressed the prediction on near or distant future salinization of aquifers in the Mediterranean area are the smallest group of papers published in peerreviewed journals, with only 18 of the 304 analyzed documents. This small group is mainly constituted of papers that employed density dependent numerical flow and transport models used to predict the evolution of aquifer salinization induced by CC [224-229] or by changes in land use and/or groundwater use, such as increased pumping rates [230,231]. Other authors have used simplified sharp interface models [232] or surrogate models [233] to quantify the effect of several pumping scenarios in the near future, but these approaches suffer for simplified assumptions that may hamper their validity at later stages.

A different approach has been followed by Parisi et al. [234], in which climatic drivers such as meteorological droughts are proposed as cascading events that trigger aquifer salinization. In addition, in low lying areas, other parameters such as the subsidence rate have also been employed [235]. A similar approach was used by Benini et al. [236] in which climatic balances using predicted climate scenarios were established to derive a vulnerability index to salinization, or by Slama et al. [237], who analyzed the pattern of precipitations 
and evapotranspiration via an unsaturated model to predict soil and groundwater salinization patterns. While Sušnik et al. [238] used an interdisciplinary approach to assess sea-level rise and CC impacts on the lower Nile delta, Egypt, where CC effects should be studied in light of all the previously available data, as suggested by Mabrouk et al. [226]. All the approaches used are affected by large uncertainties due to the combined effects of: (i) uncertainties linked with the aquifer characterization, e.g., the hydraulic conductivity field reconstruction, (ii) or linked to poorly known stresses, e.g., pumping and recharge rates, (iii) or linked to the climatic projections that are inherently affected by uncertainties. Nevertheless, these studies provide useful insights on the aspects that are actually less understood or less characterized and require further studies to better assess the near future development of aquifer salinization in coastal regions. For example, predictive modelling of key environmental processes (coupled reactive transport and density dependent flow) could be used if a holistic coastal management must be achieved, e.g., with the main goal of protecting natural resources. In order to investigate and model a particular coastal aquifer system, there are two types of information required: (i) assessment of the relevant biogeochemical reactions in the system, and (ii) dynamic simulation of reactive processes in the coastal system, which can be used to explore the consequences of environmental change, and produce forecasts of future fluxes (scenarios). The scenario modelling process must incorporate the evaluation of methods and techniques that can be applied to improve the management of coastal zones and should also provide the uncertainties linked with the unknown variables such as the hydrodynamic and biogeochemical parameters.

\subsubsection{Future Perspective of Coastal Aquifers' Salinization in the Mediterranean Area}

The integrated coastal aquifer management in the whole Mediterranean area is a key issue that must be tackled in the near future to defend freshwater resources in presence of CC and the related sea level rise. The number of peer review studies has grown fast in the last decade, but despite this increase, there are many areas of the Mediterranean coastal aquifers that have not yet received the appropriate attention. This is a stringent requirement to reach the target of optimizing water management strategies in coastal areas. Moreover, there is still a lack of studies addressing the temporal variations in groundwater quality in coastal aquifers. This information is pivotal to obtain a long-term view of aquifer salinization processes to permit to adapt and modulate the monitoring strategies to better capture salinization and freshening trends. Thus, it is urgent to create network of permanent monitoring wells equipped with MLSs by local authorities to collect time series data of water quality in coastal aquifers. However, it must be pointed out that an efficient coastal aquifer monitoring at the Mediterranean scale is maybe beyond the effective possibilities due to long lasting conflicts and to the wide extension of the coastline. Many papers have reported strong signals that some Mediterranean aquifers are critically overexploited and that corrective actions must be undertaken eventually at the whole watershed scale if a good balance between sink and sources must be obtained. This can be achieved via complex three-dimensional numerical models, but these models need a large amount of data to be considered reliable and robust. Solving the near and mid-term future coastal aquifer management in the whole Mediterranean area is a challenge that extends far beyond the actual studies and requires international cooperation and agencies specifically focused on this highly stressed region working together for a holistic approach to such a multifaceted problem. Thus, the major goal for the coming research will be to provide studies that widen the local perspective towards the regional perspective since many coastal aquifers are also transboundary aquifers. To start tackling this challenge, a common monitoring strategy should be started with the aim of gaining a publicly shared database that could be used by both the academic and professional communities to manage coastal Mediterranean aquifers. 


\section{Concluding Remarks}

From the literature review here exposed, it is apparent that some aspects have been covered with much more detail than others in the Mediterranean area, such as the use of IDS in long screen wells to characterize the origin of salinization. This is easily explained by the fact that the construction and maintenance of MLSs networks is expensive and time consuming, while already existing wells are often the only means to access groundwater to be sampled in remote regions. Nevertheless, it has been demonstrated by many authors that the use of IDS may lead to biased results due to artificial mixing within or near the well screen and casing, especially in the presence of saline and freshwater lenses. Geophysical techniques can partially overcome the issue of vertical and spatial characterization, but since they are measuring electrical and magnetic properties, indirectly related to salinization, they must be compelled by control points where direct measurements are available to verify the obtained geophysical results.

The number of studies focusing on predictions of CC effects on coastal aquifers are growing but are still very limited and surely require further research. Another urgent requirement is to create conceptual (and possibly numerical) models that include the groundwater dependent ecosystems components and social dimensions (agricultural, industrial and urban) to better manage these critical environments.

Author Contributions: Conceptualization, M.M. and N.C.; methodology, M.M.; validation, N.C.; formal analysis, M.M.; data curation, M.M.; writing-original draft preparation, M.M. and N.C.; writing-review and editing, M.M. and N.C.; visualization, M.M. and N.C. All authors have read and agreed to the published version of the manuscript.

Funding: This research received no external funding.

Data Availability Statement: The data presented in this study are available on request from the corresponding author. The data are not publicly available due to the Scopus database restriction access only to subscribers.

Conflicts of Interest: The authors declare no conflict of interest.

\section{References}

1. Bates, B.C.; Kundzewicz, Z.W.; Wu, S.; Palutikof, J.P. Climate Change and Water; IPCC Technical Paper VI; Intergovernmental Panel on Climate Change Secretariat: Geneva, Switzerland, 2008; 210p.

2. Giorgi, F. Thirty Years of Regional Climate Modeling: Where Are We and Where Are We Going next? J. Geophys. Res. Atmos. 2019, 124, 5696-5723. [CrossRef]

3. Ramanathan, V.; Crutzen, P.J.; Kiehl, J.T.; Rosenfeld, D. Aerosols, Climate, and the Hydrological Cycle. Science 2001, 294, 2119-2124. [CrossRef]

4. Hirabayashi, Y.; Mahendran, R.; Koirala, S.; Konoshima, L.; Yamazaki, D.; Watanabe, S.; Kim, H.; Kanae, S. Global flood risk under climate change. Nat. Clim. Chang. 2013, 3, 816-821. [CrossRef]

5. Milly, P.C.D.; Dunne, K.A.; Vecchia, A.V. Global pattern of trends in streamflow and water availability in a changing climate. Nat. Cell Biol. 2005, 438, 347-350. [CrossRef]

6. Taylor, R.G.; Scanlon, B.; Döll, P.; Rodell, M.; Van Beek, R.; Wada, Y.; Longuevergne, L.; Leblanc, M.; Famiglietti, J.S.; Edmunds, M.; et al. Ground water and climate change. Nat. Clim. Chang. 2013, 3, 322-329. [CrossRef]

7. Green, T.R.; Taniguchi, M.; Kooi, H.; Gurdak, J.J.; Allen, D.M.; Hiscock, K.M.; Treidel, H.; Aureli, A. Beneath the surface of global change: Impacts of climate change on groundwater. J. Hydrol. 2011, 405, 532-560. [CrossRef]

8. Seager, R.; Ting, M.; Held, I.; Kushnir, Y.; Lu, J.; Vecchi, G.; Huang, H.-P.; Harnik, N.; Leetmaa, A.; Lau, N.-C.; et al. Model Projections of an Imminent Transition to a More Arid Climate in Southwestern North America. Science 2007, 316, 1181-1184. [CrossRef]

9. Reynolds, J.F.; Smith, D.M.S.; Lambin, E.F.; Turner, B.L.; Mortimore, M.J.; Batterbury, S.P.J.; Downing, T.E.; Dowlatabadi, H.; Fernández, R.J.; Herrick, J.E.; et al. Global Desertification: Building a Science for Dryland Development. Science 2007, 316, 847-851. [CrossRef]

10. Custodio, E. Coastal aquifers of Europe: An overview. Hydrogeol. J. 2009, 18, 269-280. [CrossRef]

11. Candela, L.; Von Igel, W.; Elorza, F.J.; Aronica, G. Impact assessment of combined climate and management scenarios on groundwater resources and associated wetland (Majorca, Spain). J. Hydrol. 2009, 376, 510-527. [CrossRef]

12. Foster, S.; Chilton, P.J. Groundwater: The processes and global significance of aquifer degradation. Philos. Trans. R. Soc. B Biol. Sci. 2003, 358, 1957-1972. [CrossRef] [PubMed] 
13. Custodio, E. Seawater Intrusion in Coastal Aquifers: Guidelines for Study, Monitoring and Control; Water Reports 11; Food and Agriculture Organization of the United Nations: Rome, Italy, 1997; 152p.

14. Bear, J.; Cheng, A.H.-D.; Sorek, S.; Ouazar, D.; Herrera, I. Seawater Intrusion in Coastal Aquifers: Concepts, Methods and Practices; Kluwer Academic Publishers: Dordrecht, The Netherlands, 1999; 625p.

15. Werner, A.D.; Bakker, M.; Post, V.E.A.; Vandenbohede, A.; Lu, C.; Ataie-Ashtiani, B.; Simmons, C.T.; Barry, D. Seawater intrusion processes, investigation and management: Recent advances and future challenges. Adv. Water Resour. 2013, 51, 3-26. [CrossRef]

16. Vengosh, A. Salinization and Saline Environments. In Treatise on Geochemistry; Elsevier: Amsterdam, The Netherlands, 2003; Volume 9, pp. 1-35. [CrossRef]

17. Mirzavand, M.; Ghasemieh, H.; Sadatinejad, S.J.; Bagheri, R. An overview on source, mechanism and investigation approaches in groundwater salinization studies. Int. J. Environ. Sci. Technol. 2020, 17, 2463-2476. [CrossRef]

18. Li, C.; Gao, X.; Li, S.; Bundschuh, J. A review of the distribution, sources, genesis, and environmental concerns of salinity in groundwater. Environ. Sci. Pollut. Res. 2020, 27, 41157-41174. [CrossRef] [PubMed]

19. Tully, K.L.; Gedan, K.; Epanchin-Niell, R.; Strong, A.; Bernhardt, E.S.; Bendor, T.; Mitchell, M.; Kominoski, J.; Jordan, T.E.; Neubauer, S.C.; et al. The Invisible Flood: The Chemistry, Ecology, and Social Implications of Coastal Saltwater Intrusion. BioScience 2019, 69, 368-378. [CrossRef]

20. Singh, A. Salinization and drainage problems of agricultural land. Irrig. Drain. 2020, 69, 844-853. [CrossRef]

21. Polemio, M.; Zuffianò, L.E. Review of Utilization Management of Groundwater at Risk of Salinization. J. Water Resour. Plan. Manag. 2020, 146, 03120002. [CrossRef]

22. Dillon, P. Future management of aquifer recharge. Hydrogeol. J. 2005, 13, 313-316. [CrossRef]

23. Greene, R.; Timms, W.; Rengasamy, P.; Arshad, M.; Cresswell, R. Soil and Aquifer Salinization: Toward an Integrated Approach for Salinity Management of Groundwater. In Integrated Groundwater Management; Springer: Cham, Switzerland, 2016; pp. 377-412.

24. Roy, D.K.; Datta, B. A Review of Surrogate Models and Their Ensembles to Develop Saltwater Intrusion Management Strategies in Coastal Aquifers. Earth Syst. Environ. 2018, 2, 193-211. [CrossRef]

25. Luterbacher, J.; Xoplaki, E.; Casty, C.; Wanner, H.; Pauling, A.; Küttel, M.; Rutishauser, T.; Brönnimann, S.; Fischer, E.; Fleitmann, D.; et al. Chapter 1 Mediterranean climate variability over the last centuries: A review. Dev. Earth Environ. Sci. 2006, 4, 27-148. [CrossRef]

26. Giorgi, F. Climate change hot-spots. Geophys. Res. Lett. 2006, 33, 08707. [CrossRef]

27. Giorgi, F.; Lionello, P. Climate change projections for the Mediterranean region. Glob. Planet. Chang. 2008, 63, 90-104. [CrossRef]

28. Molina-Navarro, E.; Trolle, D.; Martínez-Pérez, S.; Sastre-Merlín, A.; Jeppesen, E. Hydrological and water quality impact assessment of a Mediterranean limno-reservoir under climate change and land use management scenarios. J. Hydrol. 2014, 509, 354-366. [CrossRef]

29. Dai, A. Increasing drought under global warming in observations and models. Nat. Clim. Chang. 2012, 3, 52-58. [CrossRef]

30. Abd-Elhamid, H.F.; Javadi, A.A. Impact of sea level rise and over-pumping on seawater intrusion in coastal aquifers. J. Water Clim. Chang. 2011, 2, 19-28. [CrossRef]

31. Ketabchi, H.; Mahmoodzadeh, D.; Ataie-Ashtiani, B.; Simmons, C.T. Sea-level rise impacts on seawater intrusion in coastal aquifers: Review and integration. J. Hydrol. 2016, 535, 235-255. [CrossRef]

32. Malek, Ž.; Verburg, P.H.; Geijzendorffer, I.R.; Bondeau, A.; Cramer, W. Global change effects on land management in the Mediterranean region. Glob. Environ. Chang. 2018, 50, 238-254. [CrossRef]

33. Greggio, N.; Giambastiani, B.M.S.; Balugani, E.; Amaini, C.; Antonellini, M. High-Resolution Electrical Resistivity Tomography (ERT) to Characterize the Spatial Extension of Freshwater Lenses in a Salinized Coastal Aquifer. Water 2018, 10, 1067. [CrossRef]

34. Galazoulas, E.C.; Mertzanides, Y.C.; Petalas, C.P.; Kargiotis, E.K. Large Scale Electrical Resistivity Tomography Survey Correlated to Hydrogeological Data for Mapping Groundwater Salinization: A Case Study from a Multilayered Coastal Aquifer in Rhodope, Northeastern Greece. Environ. Process. 2015, 2, 19-35. [CrossRef]

35. Palacios, A.; Ledo, J.J.; Linde, N.; Luquot, L.; Bellmunt, F.; Folch, A.; Marcuello, A.; Queralt, P.; Pezard, P.A.; Martínez, L.; et al. Time-lapse cross-hole electrical resistivity tomography (CHERT) for monitoring seawater intrusion dynamics in a Mediterranean aquifer. Hydrol. Earth Syst. Sci. 2020, 24, 2121-2139. [CrossRef]

36. Himi, M.; Tapias, J.; Benabdelouahab, S.; Salhi, A.; Rivero, L.; Elgettafi, M.; El Mandour, A.; Stitou, J.; Casas, A.; Elgettafi, M. Geophysical characterization of saltwater intrusion in a coastal aquifer: The case of Martil-Alila plain (North Morocco). J. Afr. Earth Sci. 2017, 126, 136-147. [CrossRef]

37. Kazakis, N.; Pavlou, A.; Vargemezis, G.; Voudouris, K.; Soulios, G.; Pliakas, F.; Tsokas, G.N. Seawater intrusion mapping using electrical resistivity tomography and hydrochemical data. An application in the coastal area of eastern Thermaikos Gulf, Greece. Sci. Total. Environ. 2016, 543, 373-387. [CrossRef] [PubMed]

38. Agoubi, B.; Kharroubi, A.; Abida, H. Saltwater intrusion modelling in Jorf coastal aquifer, South-eastern Tunisia: Geochemical, geoelectrical and geostatistical application. Hydrol. Process. 2013, 27, 1191-1199. [CrossRef]

39. El Yaouti, F.; El Mandour, A.; Khattach, D.; Benavente, J.; Kaufmann, O. Salinization processes in the unconfined aquifer of Bou-Areg (NE Morocco): A geostatistical, geochemical, and tomographic study. Appl. Geochem. 2009, 24, 16-31. [CrossRef]

40. Eissa, M.; Mahmoud, H.H.; Shouakar-Stash, O.; El-Shiekh, A.; Parker, B. Geophysical and geochemical studies to delineate seawater intrusion in Bagoush area, Northwestern coast, Egypt. J. Afr. Earth Sci. 2016, 121, 365-381. [CrossRef] 
41. Kouzana, L.; Benassi, R.; Ben Mammou, A.; Felfoul, M.S. Geophysical and hydrochemical study of the seawater intrusion in Mediterranean semi arid zones. Case of the Korba coastal aquifer (Cap-Bon, Tunisia). J. Afr. Earth Sci. 2010, 58, $242-254$. [CrossRef]

42. Kouzana, L.; Ben Mammou, A.; Felfoul, M.S. Seawater intrusion and associated processes: Case of the Korba aquifer (Cap-Bon, Tunisia). Comptes Rendus Geosci. 2009, 341, 21-35. [CrossRef]

43. Lofi, J.; Pezard, P.; Bouchette, F.; Raynal, O.; Sabatier, P.; Denchik, N.; Levannier, A.; Dezileau, L.; Certain, R. Integrated Onshore-Offshore Investigation of a Mediterranean Layered Coastal Aquifer. Ground Water 2012, 51, 550-561. [CrossRef]

44. Duque, C.; Calvache, M.L.; Pedrera, A.; Martín-Rosales, W.; López-Chicano, M. Combined time domain electromagnetic soundings and gravimetry to determine marine intrusion in a detrital coastal aquifer (Southern Spain). J. Hydrol. 2008, 349, 536-547. [CrossRef]

45. Trabelsi, F.; Ben Mammou, A.; Tarhouni, J.; Piga, C.; Ranieri, G. Delineation of saltwater intrusion zones using the time domain electromagnetic method: The Nabeul-Hammamet coastal aquifer case study (NE Tunisia). Hydrol. Process. 2012, 27, 2004-2020. [CrossRef]

46. Chekirbane, A.; Tsujimura, M.; Kawachi, A.; Lachaal, F.; Isoda, H.; Tarhouni, J. Use of a time-domain electromagnetic method with geochemical tracers to explore the salinity anomalies in a small coastal aquifer in north-eastern Tunisia. Hydrogeol. J. 2014, 22, 1777-1794. [CrossRef]

47. Ziadi, A.; Hariga, N.T.; Tarhouni, J. Use of time-domain electromagnetic (TDEM) method to investigate seawater intrusion in the Lebna coastal aquifer of eastern Cap Bon, Tunisia. Arab. J. Geosci. 2017, 10, 492. [CrossRef]

48. Kalisperi, D.; Kouli, M.; Vallianatos, F.; Soupios, P.; Kershaw, S.; Simantiris, N.L. A Transient ElectroMagnetic (TEM) Method Survey in North-Central Coast of Crete, Greece: Evidence of Seawater Intrusion. Geosciences 2018, 8, 107. [CrossRef]

49. Viezzoli, A.; Tosi, L.; Teatini, P.; Silvestri, S. Surface water-groundwater exchange in transitional coastal environments by airborne electromagnetics: The Venice Lagoon example. Geophys. Res. Lett. 2010, 37. [CrossRef]

50. Tal, A.; Weinstein, Y.; Baïsset, M.; Golan, A.; Yechieli, Y. Tal High Resolution Monitoring of Seawater Intrusion in a Multi-Aquifer System-Implementation of a New Downhole Geophysical Tool. Water 2019, 11, 1877. [CrossRef]

51. Folch, A.; Del Val, L.; Luquot, L.; Martínez-Pérez, L.; Bellmunt, F.; Le Lay, H.; Rodellas, V.; Ferrer, N.; Palacios, A.; Fernández, S.; et al. Combining fiber optic DTS, cross-hole ERT and time-lapse induction logging to characterize and monitor a coastal aquifer. J. Hydrol. 2020, 588, 125050. [CrossRef]

52. Russak, A.; Sivan, O.; Yechieli, Y. Trace elements (Li, B, Mn and Ba) as sensitive indicators for salinization and freshening events in coastal aquifers. Chem. Geol. 2016, 441, 35-46. [CrossRef]

53. Jorreto, S.; Pulido-Bosch, A.; Gisbert, J.; Sánchez-Martos, F.; Francés, I. The fresh water-seawater contact in coastal aquifers supporting intensive pumped seawater extractions: A case study. Comptes Rendus Geosci. 2009, 341, 993-1002. [CrossRef]

54. Petalas, C.; Pisinaras, V.; Gemitzi, A.; Tsihrintzis, V.A.; Ouzounis, K. Current conditions of saltwater intrusion in the coastal Rhodope aquifer system, northeastern Greece. Desalination 2009, 237, 22-41. [CrossRef]

55. Colombani, N.; Volta, G.; Osti, A.; Mastrocicco, M. Misleading reconstruction of seawater intrusion via integral depth sampling. J. Hydrol. 2016, 536, 320-326. [CrossRef]

56. Shalev, E.; Lazar, A.; Wollman, S.; Kington, S.; Yechieli, Y.; Gvirtzman, H. Biased Monitoring of Fresh Water-Salt Water Mixing Zone in Coastal Aquifers. Ground Water 2008, 47, 49-56. [CrossRef] [PubMed]

57. Mastrocicco, M.; Giambastiani, B.M.S.; Severi, P.; Colombani, N. The Importance of Data Acquisition Techniques in Saltwater Intrusion Monitoring. Water Resour. Manag. 2012, 26, 2851-2866. [CrossRef]

58. Mercado, A. The Use of Hydrogeochemical Patterns in Carbonate Sand and Sandstone Aquifers to Identify Intrusion and Flushing of Saline Water. Ground Water 1985, 23, 635-645. [CrossRef]

59. Melloul, A.; Azmon, B. A graphic expression of salinization and pollution of groundwater The case of Israel's groundwater. Environ. Earth Sci. 1997, 30, 126-136. [CrossRef]

60. Petalas, C.P. A preliminary assessment of hydrogeological features and selected anthropogenic impacts on an alluvial fan aquifer system in Greece. Environ. Earth Sci. 2012, 70, 439-452. [CrossRef]

61. Capaccioni, B.; Didero, M.; Paletta, C.; Didero, L. Saline intrusion and refreshening in a multilayer coastal aquifer in the Catania Plain (Sicily, Southern Italy): Dynamics of degradation processes according to the hydrochemical characteristics of groundwaters. J. Hydrol. 2005, 307, 1-16. [CrossRef]

62. Hermides, D.; Kyriazis, D.; Makri, P.; Ermidou, A. Geochemical evolution of the Thriassion Plain groundwaters, Attica, Greece. Environ. Monit. Assess. 2020, 192, 1-21. [CrossRef]

63. Hermides, D.; Stamatis, G. Origin of halogens and their use as environmental tracers in aquifers of Thriassion Plain, Attica, Greece. Environ. Earth Sci. 2017, 76, 306. [CrossRef]

64. Pittalis, D.; Carletti, A.; Ghiglieri, G.; Celico, F. The influence of hydrogeological properties, seawater intrusion and refreshening on the quality of groundwater used for irrigation in an agricultural coastal plain in North Sardinia, Italy. Environ. Earth Sci. 2016, 75, 963. [CrossRef]

65. Summa, V.; Margiotta, S.; Tateo, F. Correlation between geochemical, mineralogical and physical characters of sediments and salinization phenomena in a pilot area in the ionian plain (Southern Italy). Geomat. Nat. Hazards Risk 2019, 10, 1139-1154. [CrossRef] 
66. Stamatis, G.; Voudouris, K. Marine and human activity influences on the groundwater quality of southern Korinthos area (Greece). Hydrol. Process. 2003, 17, 2327-2345. [CrossRef]

67. Rouabhia, A.; Larbi, D.; Rihab, H.; Fethi, B.; Chemseddine, F.; Azzedine, H. Geochemical characterization of groundwater from shallow aquifer surrounding Fetzara Lake N. E. Algeria. Arab. J. Geosci. 2010, 5, 1-13. [CrossRef]

68. Lebid, H.; Errih, M.; Boudjemline, D. Contribution of strontium to the study of groundwater salinity. Case of the alluvial plain of Sidi Bel Abbes (Northwestern Algeria). Environ. Earth Sci. 2016, 75, 947. [CrossRef]

69. Alfarrah, N.; Walraevens, K. Groundwater Overexploitation and Seawater Intrusion in Coastal Areas of Arid and Semi-Arid Regions. Water 2018, 10, 143. [CrossRef]

70. Martos, F.S.; Pulido-Bosch, A.; Calaforra, J. Hydrogeochemical processes in an arid region of Europe (Almeria, SE Spain). Appl. Geochem. 1999, 14, 735-745. [CrossRef]

71. Souid, F.; Agoubi, B.; Telahigue, F.; Chahlaoui, A.; Kharroubi, A. Groundwater salinization and seawater intrusion tracing based on Lithium concentration in the shallow aquifer of Jerba Island, southeastern Tunisia. J. Afr. Earth Sci. 2018, 138, 233-246. [CrossRef]

72. Telahigue, F.; Mejri, H.; Mansouri, B.; Souid, F.; Agoubi, B.; Chahlaoui, A.; Kharroubi, A. Assessing seawater intrusion in arid and semi-arid Mediterranean coastal aquifers using geochemical approaches. Phys. Chem. Earth Parts A/B/C 2020, $115,102811$. [CrossRef]

73. Bicalho, C.C.; Batiot-Guilhe, C.; Seidel, J.; Van Exter, S.; Jourde, H. Geochemical evidence of water source characterization and hydrodynamic responses in a karst aquifer. J. Hydrol. 2012, 2012, 206-218. [CrossRef]

74. Giménez-Forcada, E.; Bencini, A.; Pranzini, G. Hydrogeochemical considerations about the origin of groundwater salinization in some coastal plains of Elba Island (Tuscany, Italy). Environ. Geochem. Health 2009, 32, 243-257. [CrossRef]

75. Alfarrah, N.; Berhane, G.; Bakundukize, C.; Walraevens, K. Degradation of groundwater quality in coastal aquifer of Sabratah area, NW Libya. Environ. Earth Sci. 2017, 76, 664. [CrossRef]

76. Sappa, G.; Iacurto, S.; Ferranti, F.; De Filippi, F.M. Groundwater Quality Assessment in a Karst Coastal Region of the West Aurunci Mountains (Central Italy). Geofluids 2019, 2019, 1-14. [CrossRef]

77. Brehme, M.; Scheytt, T.; Çelik, M.; Dokuz, U.E. Hydrochemical characterisation of ground and surface water at Dörtyol/Hatay/Turkey. Environ. Earth Sci. 2010, 63, 1395-1408. [CrossRef]

78. Ghiglieri, G.; Oggiano, G.; Fidelibus, M.D.; Alemayehu, T.; Barbieri, G.; Vernier, A. Hydrogeology of the Nurra Region, Sardinia (Italy): Basement-cover influences on groundwater occurrence and hydrogeochemistry. Hydrogeol. J. 2008, 17, 447-466. [CrossRef]

79. Stamatis, G.; Lambrakis, N.; Alexakis, D.E.; Zagana, E. Groundwater quality in Mesogea basin in eastern Attica (Greece). Hydrol. Process. 2006, 20, 2803-2818. [CrossRef]

80. Giménez-Forcada, E.; Vega, M. Arsenic, barium, strontium and uranium geochemistry and their utility as tracers to characterize groundwaters from the Espadán-Calderona Triassic Domain, Spain. Sci. Total. Environ. 2015, 512, 599-612. [CrossRef] [PubMed]

81. Alcalá, F.J.; Custodio, E. Using the $\mathrm{Cl} / \mathrm{Br}$ ratio as a tracer to identify the origin of salinity in aquifers in Spain and Portugal. $J$. Hydrol. 2008, 359, 189-207. [CrossRef]

82. Vengosh, A.; Ben-Zvi, A. Formation of a salt plume in the Coastal Plain aquifer of Israel: The Be'er Toviyya region. J. Hydrol. 1994, 160, 21-52. [CrossRef]

83. Tiwari, A.K.; Pisciotta, A.; De Maio, M. Evaluation of groundwater salinization and pollution level on Favignana Island, Italy. Environ. Pollut. 2019, 249, 969-981. [CrossRef]

84. Vallejos, A.; Daniele, L.; Sola, F.; Molina, L.; Pulido-Bosch, A. Anthropic-induced salinization in a dolomite coastal aquifer. Hydrogeochemical processes. J. Geochem. Explor. 2020, 209, 106438. [CrossRef]

85. Greggio, N.; Giambastiani, B.M.S.; Mollema, P.N.; Laghi, M.; Capo, D.; Gabbianelli, G.; Antonellini, M.; Dinelli, E. Assessment of the Main Geochemical Processes Affecting Surface Water and Groundwater in a Low-Lying Coastal Area: Implications for Water Management. Water 2020, 12, 1720. [CrossRef]

86. Argamasilla, M.; Barberá, J.; Andreo, B. Factors controlling groundwater salinization and hydrogeochemical processes in coastal aquifers from southern Spain. Sci. Total. Environ. 2017, 580, 50-68. [CrossRef] [PubMed]

87. Ahmed, M.A.; Samie, S.G.A.; Badawy, H.A. Factors controlling mechanisms of groundwater salinization and hydrogeochemical processes in the Quaternary aquifer of the Eastern Nile Delta, Egypt. Environ. Earth Sci. 2012, 68, 369-394. [CrossRef]

88. Giambastiani, B.; Colombani, N.; Mastrocicco, M.; Fidelibus, M. Characterization of the lowland coastal aquifer of Comacchio (Ferrara, Italy): Hydrology, hydrochemistry and evolution of the system. J. Hydrol. 2013, 501, 35-44. [CrossRef]

89. Grassi, S.; Cortecci, G.; Squarci, P. Groundwater resource degradation in coastal plains: The example of the Cecina area (Tuscany-Central Italy). Appl. Geochem. 2007, 22, 2273-2289. [CrossRef]

90. Mandilaras, D.; Lambrakis, N.; Stamatis, G. The role of bromide and iodide ions in the salinization mapping of the aquifer of Glafkos River basin (northwest Achaia, Greece). Hydrol. Process. 2008, 22, 611-622. [CrossRef]

91. Trabelsi, R.; Abid, K.; Zouari, K.; Yahyaoui, H. Groundwater salinization processes in shallow coastal aquifer of Djeffara plain of Medenine, Southeastern Tunisia. Environ. Earth Sci. 2011, 66, 641-653. [CrossRef]

92. Vengosh, A.; Spivack, A.J.; Artzi, Y.; Ayalon, A. Geochemical and boron, strontium, and oxygen isotopic constraints on the origin of the salinity in groundwater from the Mediterranean Coast of Israel. Water Resour. Res. 1999, 35, 1877-1894. [CrossRef]

93. Yechieli, Y.; Sivan, O.; Lazar, B.; Vengosh, A.; Ronen, D.; Herut, B. Radiocarbon in Seawater Intruding into the Israeli Mediterranean Coastal Aquifer. Radiocarbon 2001, 43, 773-781. [CrossRef] 
94. Morell, I.; Pulido-Bosch, A.; Sánchez-Martos, F.; Vallejos, A.; Daniele, L.; Molina, L.; Calaforra, J.M.; Roig, A.F.; Renau, A. Characterization of the Salinisation Processes in Aquifers Using Boron Isotopes; Application to South-Eastern Spain. Water Air Soil Pollut. 2007, 187, 65-80. [CrossRef]

95. Gattacceca, J.C.; Vallet-Coulomb, C.; Mayer, A.; Claude, C.; Radakovitch, O.; Conchetto, E.; Hamelin, B. Isotopic and geochemical characterization of salinization in the shallow aquifers of a reclaimed subsiding zone: The southern Venice Lagoon coastland. $J$. Hydrol. 2009, 378, 46-61. [CrossRef]

96. Forcada, E.G.; Morell, I. Contributions of boron isotopes to understanding the hydrogeochemistry of the coastal detritic aquifer of Castellón Plain, Spain. Hydrogeol. J. 2008, 16, 547-557. [CrossRef]

97. Yuce, G. Determination of the recharge area and salinization degree of karst springs in the Lamas Basin (Turkey). Isot. Environ. Health Stud. 2005, 41, 391-404. [CrossRef] [PubMed]

98. Mongelli, G.; Monni, S.; Oggiano, G.; Paternoster, M.; Sinisi, R. Tracing groundwater salinization processes in coastal aquifers: A hydrogeochemical and isotopic approach in the $\mathrm{Na}-\mathrm{Cl}$ brackish waters of northwestern Sardinia, Italy. Hydrol. Earth Syst. Sci. 2013, 17, 2917-2928. [CrossRef]

99. Ben Ammar, S.; Taupin, J.-D.; Ben Alaya, M.; Zouari, K.; Patris, N.; Khouatmia, M. Using geochemical and isotopic tracers to characterize groundwater dynamics and salinity sources in the Wadi Guenniche coastal plain in northern Tunisia. J. Arid. Environ. 2020, 178, 104150. [CrossRef]

100. Pouliaris, C.; Perdikaki, M.; Foglia, L.; Schüth, C.; Kallioras, A. Hydrodynamic analysis of a Mediterranean aquifer system with the use of hydrochemical and isotopical analysis as supporting tools. Environ. Earth Sci. 2018, 77, 237. [CrossRef]

101. Zakhem, B.A.; Hafez, R. Environmental isotope study of seawater intrusion in the coastal aquifer (Syria). Environ. Earth Sci. 2006, 51, 1329-1339. [CrossRef]

102. Kumanova, X.; Marku, S.; Fröjdö, S.; Jacks, G. Recharge and sustainability of a coastal aquifer in northern Albania. Hydrogeol. J. 2014, 22, 883-892. [CrossRef]

103. Burg, A.; Gavrieli, I.; Guttman, J. Concurrent Salinization and Development of Anoxic Conditions in a Confined Aquifer, Southern Israel. Ground Water 2017, 55, 183-198. [CrossRef]

104. Caschetto, M.; Colombani, N.; Mastrocicco, M.; Petitta, M.; Aravena, R. Nitrogen and sulphur cycling in the saline coastal aquifer of Ferrara, Italy. A multi-isotope approach. Appl. Geochem. 2017, 76, 88-98. [CrossRef]

105. Eissa, M.; Shawky, H.A.; Samy, A.; Khalil, M.M.; El Malky, M. Geochemical and Isotopic Evidence of Groundwater Salinization Processes in El Dabaa Area, Northwestern Coast, Egypt. Geosciences 2018, 8, 392. [CrossRef]

106. Elgettafi, M.; Elmandour, A.; Himi, M.; Casas, A. The use of environmental markers to identify groundwater salinization sources in a Neogene basin, Kert aquifer case, NE Morocco. Int. J. Environ. Sci. Technol. 2013, 10, 719-728. [CrossRef]

107. Gemici, Ü.; Somay, M.A.; Akar, A.T.; Tarcan, G. An assessment of the seawater effect by geochemical and isotopic data on the brackish karst groundwater from the Karaburun Peninsula (İzmir, Turkey). Environ. Earth Sci. 2016, 75, 1008. [CrossRef]

108. Ben Moussa, A.; Zouari, K.; Marc, V. Hydrochemical and isotope evidence of groundwater salinization processes on the coastal plain of Hammamet-Nabeul, north-eastern Tunisia. Phys. Chem. Earth Parts A/B/C 2011, 36, 167-178. [CrossRef]

109. Re, V.; Sacchi, E.; Mas-Pla, J.; Menció, A.; El Amrani, N. Identifying the effects of human pressure on groundwater quality to support water management strategies in coastal regions: A multi-tracer and statistical approach (Bou-Areg region, Morocco). Sci. Total. Environ. 2014, 500, 211-223. [CrossRef] [PubMed]

110. Petelet-Giraud, E.; Négrel, P.; Aunay, B.; Ladouche, B.; Bailly-Comte, V.; Guerrot, C.; Flehoc, C.; Pezard, P.; Lofi, J.; Dörfliger, N. Coastal groundwater salinization: Focus on the vertical variability in a multi-layered aquifer through a multi-isotope fingerprinting (Roussillon Basin, France). Sci. Total. Environ. 2016, 566, 398-415. [CrossRef]

111. Vallet-Coulomb, C.; Séraphin, P.; Gonçalvès, J.; Radakovitch, O.; Cognard-Plancq, A.-L.; Crespy, A.; Babic, M.; Charron, F. Irrigation return flows in a mediterranean aquifer inferred from combined chloride and stable isotopes mass balances. Appl. Geochem. 2017, 86, 92-104. [CrossRef]

112. Telahigue, F.; Souid, F.; Agoubi, B.; Chahlaoui, A.; Kharroubi, A. Hydrogeochemical and isotopic evidence of groundwater salinization in a coastal aquifer: A case study in Jerba Island, southeastern Tunisia. Phys. Chem. Earth Parts A/B/C 2020, 118, 102886. [CrossRef]

113. Souid, F.; Telahigue, F.; Agoubi, B.; Kharroubi, A. Isotopic behavior and self-organizing maps for identifying groundwater salinization processes in Jerba Island, Tunisia. Environ. Earth Sci. 2020, 79, 1-10. [CrossRef]

114. Yechieli, Y.; Kafri, U.; Sivan, O. The inter-relationship between coastal sub-aquifers and the Mediterranean Sea, deduced from radioactive isotopes analysis. Hydrogeol. J. 2008, 17, 265-274. [CrossRef]

115. El Samad, O.; Baydoun, R.; Aoun, M.; Slim, K. Investigation of seawater intrusion using stable and radioisotopes at coastal area south of Beirut, the Capital of Lebanon. Environ. Earth Sci. 2017, 76, 187. [CrossRef]

116. Yechieli, Y.; Yokochi, R.; Zilberbrand, M.; Lu, Z.-T.; Purtschert, R.; Sueltenfuss, J.; Jiang, W.; Zappala, J.; Mueller, P.; Bernier, R.; et al. Recent seawater intrusion into deep aquifer determined by the radioactive noble-gas isotopes 81Kr and 39Ar. Earth Planet. Sci. Lett. 2019, 507, 21-29. [CrossRef]

117. Mayer, A.; Nguyen, B.T.; Banton, O. Using radon-222 to study coastal groundwater/surface-water interaction in the Crau coastal aquifer (southeastern France). Hydrogeol. J. 2016, 24, 1775-1789. [CrossRef] 
118. Güler, C.; Kurt, M.A.; Alpaslan, M.; Akbulut, C. Assessment of the impact of anthropogenic activities on the groundwater hydrology and chemistry in Tarsus coastal plain (Mersin, SE Turkey) using fuzzy clustering, multivariate statistics and GIS techniques. J. Hydrol. 2012, 2012, 435-451. [CrossRef]

119. Abu-Alnaeem, M.F.; Yusoff, I.; Fatt, N.T.; Alias, Y.; Raksmey, M. Assessment of groundwater salinity and quality in Gaza coastal aquifer, Gaza Strip, Palestine: An integrated statistical, geostatistical and hydrogeochemical approaches study. Sci. Total. Environ. 2018, 615, 972-989. [CrossRef]

120. Acikel, S.; Ekmekci, M. Assessment of groundwater quality using multivariate statistical techniques in the Azmak Spring Zone, Mugla, Turkey. Environ. Earth Sci. 2018, 77, 753. [CrossRef]

121. Masoud, A.A. Groundwater quality assessment of the shallow aquifers west of the Nile Delta (Egypt) using multivariate statistical and geostatistical techniques. J. Afr. Earth Sci. 2014, 95, 123-137. [CrossRef]

122. Papatheodorou, G.N.; Lambrakis, N.; Panagopoulos, G. Application of multivariate statistical procedures to the hydrochemical study of a coastal aquifer: An example from Crete, Greece. Hydrol. Process. 2007, 21, 1482-1495. [CrossRef]

123. Telahigue, F.; Agoubi, B.; Souid, F.; Kharroubi, A. Assessment of seawater intrusion in an arid coastal aquifer, south-eastern Tunisia, using multivariate statistical analysis and chloride mass balance. Phys. Chem. Earth Parts A/B/C 2018, 106, 37-46. [CrossRef]

124. Trabelsi, R.; Zairi, M.; Ben Dhia, H. Groundwater salinization of the Sfax superficial aquifer, Tunisia. Hydrogeol. J. 2007, 15, 1341-1355. [CrossRef]

125. Triki, I.; Trabelsi, N.; Zairi, M.; Ben Dhia, H. Multivariate statistical and geostatistical techniques for assessing groundwater salinization in Sfax, a coastal region of eastern Tunisia. Desalin. Water Treat. 2013, 52, 1980-1989. [CrossRef]

126. Voutsis, N.; Kelepertzis, E.; Tziritis, E.P.; Kelepertsis, A. Assessing the hydrogeochemistry of groundwaters in ophiolite areas of Euboea Island, Greece, using multivariate statistical methods. J. Geochem. Explor. 2015, 159, 79-92. [CrossRef]

127. Slama, F.; Bouhlila, R. Multivariate statistical analysis and hydrogeochemical modelling of seawater-freshwater mixing along selected flow paths: Case of Korba coastal aquifer Tunisia. Estuar. Coast. Shelf Sci. 2017, 198, 636-647. [CrossRef]

128. Alfio, M.R.; Balacco, G.; Parisi, A.; Totaro, V.; Fidelibus, M.D. Drought Index as Indicator of Salinization of the Salento Aquifer (Southern Italy). Water 2020, 12, 1927. [CrossRef]

129. Zaccaria, D.; Passarella, G.; D’Agostino, D.; Giordano, R.; Solis, S.S. Risk Assessment of Aquifer Salinization in a Large-Scale Coastal Irrigation Scheme, Italy. Clean Soil Air Water 2016, 44, 371-382. [CrossRef]

130. Gontara, M.; Allouche, N.; Jmal, I.; Bouri, S. Sensitivity analysis for the GALDIT method based on the assessment of vulnerability to pollution in the northern Sfax coastal aquifer, Tunisia. Arab. J. Geosci. 2016, 9, 416. [CrossRef]

131. Kazakis, N.; Spiliotis, M.; Voudouris, K.; Pliakas, F.-K.; Papadopoulos, B. A fuzzy multicriteria categorization of the GALDIT method to assess seawater intrusion vulnerability of coastal aquifers. Sci. Total. Environ. 2018, 621, 524-534. [CrossRef]

132. Trabelsi, N.; Triki, I.; Hentati, I.; Zairi, M. Aquifer vulnerability and seawater intrusion risk using GALDIT, GQISWI and GIS: Case of a coastal aquifer in Tunisia. Environ. Earth Sci. 2016, 75, 1-19. [CrossRef]

133. Bouderbala, A.; Rémini, B.; Hamoudi, A.S.; Pulido-Bosch, A. Assessment of groundwater vulnerability and quality in coastal aquifers: A case study (Tipaza, North Algeria). Arab. J. Geosci. 2016, 9, 1-12. [CrossRef]

134. Pedreira, R.; Kallioras, A.; Pliakas, F.; Gkiougkis, I.; Schuth, C. Groundwater vulnerability assessment of a coastal aquifer system at River Nestos eastern Delta, Greece. Environ. Earth Sci. 2015, 73, 6387-6415. [CrossRef]

135. Allouche, N.; Maanan, M.; Gontara, M.; Rollo, N.; Jmal, I.; Bouri, S. A global risk approach to assessing groundwater vulnerability. Environ. Model. Softw. 2017, 88, 168-182. [CrossRef]

136. Kazakis, N.; Busico, G.; Colombani, N.; Mastrocicco, M.; Pavlou, A.; Voudouris, K. GALDIT-SUSI a modified method to account for surface water bodies in the assessment of aquifer vulnerability to seawater intrusion. J. Environ. Manag. 2019, 235, 257-265. [CrossRef] [PubMed]

137. Semar, A.; Saibi, H. Multiparameter cartographic assessment of the hydrochemical groundwater of the Soummam valley (Kabylia, Algeria). Environ. Prog. Sustain. Energy 2014, 33, 1357-1365. [CrossRef]

138. Somay, M.A.; Gemici, Ü. Assessment of the Salinization Process at the Coastal Area with Hydrogeochemical Tools and Geographical Information Systems (GIS): Selçuk Plain, Izmir, Turkey. Water Air Soil Pollut. 2008, 201, 55-74. [CrossRef]

139. Rachid, G.; El-Fadel, M.; Najm, M.A.; Alameddine, I. Towards a framework for the assessment of saltwater intrusion in coastal aquifers. Environ. Impact Assess. Rev. 2017, 67, 10-22. [CrossRef]

140. Tomaszkiewicz, M.; Najm, M.A.; El-Fadel, M. Development of a groundwater quality index for seawater intrusion in coastal aquifers. Environ. Model. Softw. 2014, 57, 13-26. [CrossRef]

141. Ding, Z.; Koriem, M.A.; Ibrahim, S.M.; Antar, A.S.; Ewis, M.A.; He, Z.; Kheir, A.M. Seawater intrusion impacts on groundwater and soil quality in the northern part of the Nile Delta, Egypt. Environ. Earth Sci. 2020, 79, 1-11. [CrossRef]

142. Ferchichi, H.; Ben Hamouda, M.F.; Farhat, B.; Ben Mammou, A. Assessment of groundwater salinity using GIS and multivariate statistics in a coastal Mediterranean aquifer. Int. J. Environ. Sci. Technol. 2018, 15, 2473-2492. [CrossRef]

143. Da Lio, C.; Carol, E.; Kruse, E.E.; Teatini, P.; Tosi, L. Saltwater contamination in the managed low-lying farmland of the Venice coast, Italy: An assessment of vulnerability. Sci. Total. Environ. 2015, 533, 356-369. [CrossRef]

144. Abarca, E.; Carrera, J.; Capino, B.; Gamez, D.; Batlle, F.; Suñé, E.V. Optimal design of measures to correct seawater intrusion. Water Resour. Res. 2006, 42. [CrossRef] 
145. Karatzas, G.P.; Dokou, Z. Optimal management of saltwater intrusion in the coastal aquifer of Malia, Crete (Greece), using particle swarm optimization. Hydrogeol. J. 2015, 23, 1181-1194. [CrossRef]

146. Ziogas, A.I.; Kaleris, V.K. Establishing and Calibrating the Model of a Coastal Aquifer with Limited Data for Assessing the Safety of the Groundwater Exploitation. Water Resour. Manag. 2019, 33, 2693-2709. [CrossRef]

147. Khadra, W.M.; Stuyfzand, P.J. Simulation of saltwater intrusion in a poorly karstified coastal aquifer in Lebanon (Eastern Mediterranean). Hydrogeol. J. 2018, 26, 1839-1856. [CrossRef]

148. Iribar, V.; Carrera, J.; Custodio, E.; Medina, A. Inverse modelling of seawater intrusion in the Llobregat delta deep aquifer. J. Hydrol. 1997, 198, 226-244. [CrossRef]

149. Jarray, H.; Zammouri, M.; Ouessar, M. Assessment of groundwater salinization using PEST and sensitivity analysis: Case of Zeuss-Koutine and Mio-Plio-Quaternary aquifers. Arab. J. Geosci. 2020, 13, 1-16. [CrossRef]

150. Kerrou, J.; Renard, P.; Lecca, G.; Tarhouni, J. Grid-enabled Monte Carlo analysis of the impacts of uncertain discharge rates on seawater intrusion in the Korba aquifer (Tunisia). Hydrol. Sci. J. 2010, 55, 1325-1336. [CrossRef]

151. Stein, S.; Sola, F.; Yechieli, Y.; Shalev, E.; Sivan, O.; Kasher, R.; Vallejos, A. The effects of long-term saline groundwater pumping for desalination on the fresh-saline water interface: Field observations and numerical modeling. Sci. Total. Environ. 2020, 732, 139249. [CrossRef]

152. Tal, A.; Weinstein, Y.; Wollman, S.; Goldman, M.; Yechieli, Y. The Interrelations between a Multi-Layered Coastal Aquifer, a Surface Reservoir (Fish Ponds), and the Sea. Water 2018, 10, 1426. [CrossRef]

153. Haaken, K.; Deidda, G.P.; Cassiani, G.; Deiana, R.; Putti, M.; Paniconi, C.; Scudeler, C.; Kemna, A. Flow dynamics in hyper-saline aquifers: Hydro-geophysical monitoring and modeling. Hydrol. Earth Syst. Sci. 2017, 21, 1439-1454. [CrossRef]

154. Koukadaki, M.A.; Karatzas, G.P.; Papadopoulou, M.P.; Vafidis, A. Identification of the Saline Zone in a Coastal Aquifer Using Electrical Tomography Data and Simulation. Water Resour. Manag. 2007, 21, 1881-1898. [CrossRef]

155. Masciopinto, C.; Liso, I.S.; Caputo, M.C.; De Carlo, L. An Integrated Approach Based on Numerical Modelling and Geophysical Survey to Map Groundwater Salinity in Fractured Coastal Aquifers. Water 2017, 9, 875. [CrossRef]

156. Siarkos, I.; Latinopoulos, D.; Mallios, Z.; Latinopoulos, P. A methodological framework to assess the environmental and economic effects of injection barriers against seawater intrusion. J. Environ. Manag. 2017, 193, 532-540. [CrossRef] [PubMed]

157. Russak, A.; Sivan, O. Hydrogeochemical Tool to Identify Salinization or Freshening of Coastal Aquifers Determined from Combined Field Work, Experiments, and Modeling. Environ. Sci. Technol. 2010, 44, 4096-4102. [CrossRef] [PubMed]

158. Campana, C.; Fidelibus, M.D. Reactive-transport modelling of gypsum dissolution in a coastal karst aquifer in Puglia, southern Italy. Hydrogeol. J. 2015, 23, 1381-1398. [CrossRef]

159. Khadra, W.M.; Stuyfzand, P.J.; Van Breukelen, B.M. Hydrochemical effects of saltwater intrusion in a limestone and dolomitic limestone aquifer in Lebanon. Appl. Geochem. 2017, 79, 36-51. [CrossRef]

160. Alagha, J.S.; Seyam, M.; Said, A.M.; Mogheir, Y. Integrating an artificial intelligence approach with k-means clustering to model groundwater salinity: The case of Gaza coastal aquifer (Palestine). Hydrogeol. J. 2017, 25, 2347-2361. [CrossRef]

161. Romić, D.; Castrignanò, A.; Romić, M.; Buttafuoco, G.; Kovačić, M.B.; Ondrasek, G.; Zovko, M. Modelling spatial and temporal variability of water quality from different monitoring stations using mixed effects model theory. Sci. Total. Environ. 2020, 704, 135875. [CrossRef]

162. Karterakis, S.M.; Karatzas, G.P.; Nikolos, I.K.; Papadopoulou, M.P. Application of linear programming and differential evolutionary optimization methodologies for the solution of coastal subsurface water management problems subject to environmental criteria. J. Hydrol. 2007, 342, 270-282. [CrossRef]

163. Felisa, G.; Ciriello, V.; Antonellini, M.A.; Di Federico, V.; Tartakovsky, D.M. Data-driven models of groundwater salinization in coastal plains. J. Hydrol. 2015, 531, 187-197. [CrossRef]

164. Mazi, A.; Koussis, A.D.; Destouni, G. Intensively exploited Mediterranean aquifers: Resilience to seawater intrusion and proximity to critical thresholds. Hydrol. Earth Syst. Sci. 2014, 18, 1663-1677. [CrossRef]

165. Giménez-Forcada, E.; Román, F.J.S.S. An Excel Macro to Plot the HFE-Diagram to Identify Sea Water Intrusion Phases. Ground Water 2014, 53, 819-824. [CrossRef]

166. Amir, N.; Kafri, U.; Herut, B.; Shalev, E. Numerical Simulation of Submarine Groundwater Flow in the Coastal Aquifer at the Palmahim Area, the Mediterranean Coast of Israel. Water Resour. Manag. 2013, 27, 4005-4020. [CrossRef]

167. Barazzuoli, P.; Nocchi, M.; Rigati, R.; Salleolini, M. A conceptual and numerical model for groundwater management: A case study on a coastal aquifer in southern Tuscany, Italy. Hydrogeol. J. 2008, 16, 1557-1576. [CrossRef]

168. Paldor, A.; Shalev, E.; Katz, O.; Aharonov, E. Dynamics of saltwater intrusion and submarine groundwater discharge in confined coastal aquifers: A case study in northern Israel. Hydrogeol. J. 2019, 27, 1611-1625. [CrossRef]

169. Gossel, W.; Sefelnasr, A.; Wycisk, P. Modelling of paleo-saltwater intrusion in the northern part of the Nubian Aquifer System, Northeast Africa. Hydrogeol. J. 2010, 18, 1447-1463. [CrossRef]

170. Van Engelen, J.; Verkaik, J.; King, J.; Nofal, E.R.; Bierkens, M.; Essink, G.O. A three-dimensional palaeohydrogeological reconstruction of the groundwater salinity distribution in the Nile Delta Aquifer. Hydrol. Earth Syst. Sci. 2019, 23, 5175-5198. [CrossRef]

171. Chkirbene, A.; Tsujimura, M.; Kawachi, A.; Isoda, H.; Tarhouni, J.; Benalaya, A. 3D simulation of a multi-stressed coastal aquifer, northeast of Tunisia: Salt transport processes and remediation scenarios. Environ. Earth Sci. 2014, 73, 1427-1442. [CrossRef] 
172. Abd-Elhamid, H.F.; Javadi, A.; Abdelaty, I.; Sherif, M. Simulation of seawater intrusion in the Nile Delta aquifer under the conditions of climate change. Hydrol. Res. 2016, 47, 1198-1210. [CrossRef]

173. Qahman, K.; Larabi, A. Evaluation and numerical modeling of seawater intrusion in the Gaza aquifer (Palestine). Hydrogeol. J. 2006, 14, 713-728. [CrossRef]

174. Yakirevich, A.; Melloul, A.J.; Sorek, S.; Shaath, S.; Borisov, V.S. Simulation of seawater intrusion into the Khan Yunis area of the Gaza Strip coastal aquifer. Hydrogeol. J. 1998, 6, 549-559. [CrossRef]

175. Yechieli, Y.; Shalev, E.; Wollman, S.; Kiro, Y.; Kafri, U. Response of the Mediterranean and Dead Sea coastal aquifers to sea level variations. Water Resour. Res. 2010, 46. [CrossRef]

176. Magri, F.; Akar, T.; Gemici, U.; Pekdeger, A. Numerical investigations of fault-induced seawater circulation in the SeferihisarBalçova Geothermal system, western Turkey. Hydrogeol. J. 2011, 20, 103-118. [CrossRef]

177. Vespasiano, G.; Cianflone, G.; Romanazzi, A.; Apollaro, C.; Dominici, R.; Polemio, M.; De Rosa, R. A multidisciplinary approach for sustainable management of a complex coastal plain: The case of Sibari Plain (Southern Italy). Mar. Pet. Geol. 2019, 109, 740-759. [CrossRef]

178. Russak, A.; Yechieli, Y.; Herut, B.; Lazar, B.; Sivan, O. The effect of salinization and freshening events in coastal aquifers on nutrient characteristics as deduced from field data. J. Hydrol. 2015, 529, 1293-1301. [CrossRef]

179. Petalas, C.; Lambrakis, N. Simulation of intense salinization phenomena in coastal aquifers-The case of the coastal aquifers of Thrace. J. Hydrol. 2006, 324, 51-64. [CrossRef]

180. Ben Hamouda, M.F.; Tarhouni, J.; LeDuc, C.; Zouari, K. Understanding the origin of salinization of the Plio-quaternary eastern coastal aquifer of Cap Bon (Tunisia) using geochemical and isotope investigations. Environ. Earth Sci. 2010, 63, 889-901. [CrossRef]

181. Giambastiani, B.M.S.; Colombani, N.; Greggio, N.; Antonellini, M.; Mastrocicco, M. Coastal aquifer response to extreme storm events in Emilia-Romagna, Italy. Hydrol. Process. 2017, 31, 1613-1621. [CrossRef]

182. Franceschini, F.; Signorini, R. Seawater intrusion via surface water vs. deep shoreline salt-wedge: A case history from the Pisa coastal plain (Italy). Groundw. Sustain. Dev. 2016, 2, 73-84. [CrossRef]

183. Ghiglieri, G.; Carletti, A.; Pittalis, D. Analysis of salinization processes in the coastal carbonate aquifer of Porto Torres (NW Sardinia, Italy). J. Hydrol. 2012, 2012, 43-51. [CrossRef]

184. De Montety, V.; Radakovitch, O.; Vallet-Coulomb, C.; Blavoux, B.; Hermitte, D.; Valles, V. Origin of groundwater salinity and hydrogeochemical processes in a confined coastal aquifer: Case of the Rhône delta (Southern France). Appl. Geochem. 2008, 23, 2337-2349. [CrossRef]

185. Zghibi, A.; Tarhouni, J.; Zouhri, L. Assessment of seawater intrusion and nitrate contamination on the groundwater quality in the Korba coastal plain of Cap-Bon (North-east of Tunisia). J. Afr. Earth Sci. 2013, 87, 1-12. [CrossRef]

186. Rosenthal, E.; Vinokurov, A.; Ronen, D.; Magaritz, M.; Moshkovitz, S. Anthropogenically induced salinization of groundwater: A case study from the Coastal Plain aquifer of Israel. J. Contam. Hydrol. 1992, 11, 149-171. [CrossRef]

187. Scheiber, L.; Ayora, C.; Suñé, E.V.; Cendón, D.I.; Soler, A.; Custodio, E.; Baquero, J.C.; Soler, A. Recent and old groundwater in the Niebla-Posadas regional aquifer (southern Spain): Implications for its management. J. Hydrol. 2015, 523, 624-635. [CrossRef]

188. Daniele, L.; Vallejos, A.; Corbella, M.; Molina, L.; Pulido-Bosch, A. Hydrogeochemistry and geochemical simulations to assess water-rock interactions in complex carbonate aquifers: The case of Aguadulce (SE Spain). Appl. Geochem. 2013, 29 , 43-54. [CrossRef]

189. Pulido-Bosch, A. Seawater intrusion and associated processes in a small coastal complex aquifer (Castell de Ferro, Spain). Appl. Geochem. 2004, 19, 1517-1527. [CrossRef]

190. Mollema, P.; Antonellini, M.; Dinelli, E.; Gabbianelli, G.; Greggio, N.; Stuyfzand, P. Hydrochemical and physical processes influencing salinization and freshening in Mediterranean low-lying coastal environments. Appl. Geochem. 2013, 34, 207-221. [CrossRef]

191. Rosenthal, E.; Weinberger, G.; Kronfeld, J. Ground Water Salinization Caused by Residual Neogene and Pliocene Sea Water-An Example from the Judea Group Aquifer, Southern Israel. Ground Water 1999, 37, 261-270. [CrossRef]

192. Shavit, U.; Furman, A. The location of deep salinity sources in the Israeli Coastal aquifer. J. Hydrol. 2001, 250, 63-77. [CrossRef]

193. Sivan, O.; Yechieli, Y.; Herut, B.; Lazar, B. Geochemical evolution and timescale of seawater intrusion into the coastal aquifer of Israel. Geochim. Cosmochim. Acta 2005, 69, 579-592. [CrossRef]

194. Vallejos, A.; Sola, F.; Yechieli, Y.; Pulido-Bosch, A. Influence of the paleogeographic evolution on the groundwater salinity in a coastal aquifer. Cabo de Gata aquifer, SE Spain. J. Hydrol. 2018, 557, 55-66. [CrossRef]

195. Ben Cheikh, N.; Zouari, K.; Abidi, B. Geochemical and isotopic study of paleogroundwater salinization in southeastern Tunisia (Sfax basin). Quat. Int. 2012, 257, 34-42. [CrossRef]

196. Colombani, N.; Cuoco, E.; Mastrocicco, M. Origin and pattern of salinization in the Holocene aquifer of the southern Po Delta (NE Italy). J. Geochem. Explor. 2017, 175, 130-137. [CrossRef]

197. Antonellini, M.; Allen, D.; Mollema, P.N.; Capo, D.; Greggio, N. Groundwater freshening following coastal progradation and land reclamation of the Po Plain, Italy. Hydrogeol. J. 2015, 23, 1009-1026. [CrossRef]

198. Dever, L.; Travi, Y.; Barbecot, F.; Marlin, C.; Gibert, E. Evidence for palaeowaters in the coastal aquifers of France. Geol. Soc. Lond. Speéc. Publ. 2001, 189, 93-106. [CrossRef] 
199. Khaska, M.; Salle, C.L.G.L.; Lancelot, J.; Team, A.; Mohamad, A.; Verdoux, P.; Noret, A.; Simler, R. Origin of groundwater salinity (current seawater vs. saline deep water) in a coastal karst aquifer based on $\mathrm{Sr}$ and $\mathrm{Cl}$ isotopes. Case study of the La Clape massif (southern France). Appl. Geochem. 2013, 37, 212-227. [CrossRef]

200. Re, V.; Sacchi, E.; Martin-Bordes, J.; Aureli, A.; El Hamouti, N.; Bouchnan, R.; Zuppi, G. Processes affecting groundwater quality in arid zones: The case of the Bou-Areg coastal aquifer (North Morocco). Appl. Geochem. 2013, 34, 181-198. [CrossRef]

201. Ghabayen, S.M.; McKee, M.; Kemblowski, M. Ionic and isotopic ratios for identification of salinity sources and missing data in the Gaza aquifer. J. Hydrol. 2006, 318, 360-373. [CrossRef]

202. Bouzourra, H.; Bouhlila, R.; Elango, L.; Slama, F.; Ouslati, N. Characterization of mechanisms and processes of groundwater salinization in irrigated coastal area using statistics, GIS, and hydrogeochemical investigations. Environ. Sci. Pollut. Res. 2015, 22, 2643-2660. [CrossRef]

203. Sánchez-Martos, F.; Pulido-Bosch, A.; Molina-Sánchez, L.; Vallejos-Izquierdo, A. Identification of the origin of salinization in groundwater using minor ions (Lower Andarax, Southeast Spain). Sci. Total. Environ. 2002, 297, 43-58. [CrossRef]

204. D'Alessandro, W.; Bellomo, S.; Brusca, L.; Kyriakopoulos, K.; Calabrese, S.; Daskalopoulou, K. The impact of natural and anthropogenic factors on groundwater quality in an active volcanic/geothermal system under semi-arid climatic conditions: The case study of Methana peninsula (Greece). J. Geochem. Explor. 2017, 175, 110-119. [CrossRef]

205. Vengosh, A.; Kloppmann, W.; Marei, A.; Livshitz, Y.; Gutierrez, A.; Banna, M.; Guerrot, C.; Pankratov, I.; Raanan, H. Sources of salinity and boron in the Gaza strip: Natural contaminant flow in the southern Mediterranean coastal aquifer. Water Resour. Res. 2005, 41. [CrossRef]

206. Mastrorillo, L.; Mazza, R.; Manca, F.; Tuccimei, P. Evidences of different salinization sources in the roman coastal aquifer (Central Italy). J. Coast. Conserv. 2016, 20, 423-441. [CrossRef]

207. Petalas, C.P.; Diamantis, I.B. Origin and distribution of saline groundwaters in the upper Miocene aquifer system, coastal Rhodope area, northeastern Greece. Hydrogeol. J. 1999, 7, 305-316. [CrossRef]

208. Boumaiza, L.; Chesnaux, R.; Drias, T.; Walter, J.; Huneau, F.; Garel, E.; Knoeller, K.; Stumpp, C. Identifying groundwater degradation sources in a Mediterranean coastal area experiencing significant multi-origin stresses. Sci. Total. Environ. 2020, 746, 141203. [CrossRef] [PubMed]

209. Abu-Alnaeem, M.F.; Yusoff, I.; Fatt, N.T.; Maity, J.P.; Alias, Y.; May, R.; Alborsh, H. A study on the impact of anthropogenic and geogenic factors on groundwater salinization and seawater intrusion in Gaza coastal aquifer, Palestine: An integrated multi-techniques approach. J. Afr. Earth Sci. 2019, 156, 75-93. [CrossRef]

210. Yolcubal, I.; Gündüz, Ö.C.A.; Kurtuluş, N. Origin of salinization and pollution sources and geochemical processes in urban coastal aquifer (Kocaeli, NW Turkey). Environ. Earth Sci. 2019, 78, 181. [CrossRef]

211. Melloul, A.J.; Aberbach, S. Heuristic Approach for Renovating a Monitoring Network Measuring Sea Water Intrusion into the Coastal Aquifer. Ground Water Monit. Remediat. 2007, 27, 119-128. [CrossRef]

212. Djabri, L.; Ghrieb, L.; Guezgouz, N.; Hani, A.; Bouhsina, S. Impacts of morphological factors on the marine intrusion in Annaba region (east of Algeria). Desalin. Water Treat. 2013, 52, 2151-2156. [CrossRef]

213. Polemio, M. Monitoring and Management of Karstic Coastal Groundwater in a Changing Environment (Southern Italy): A Review of a Regional Experience. Water 2016, 8, 148. [CrossRef]

214. Yechieli, Y.; Sivan, O. The distribution of saline groundwater and its relation to the hydraulic conditions of aquifers and aquitards: Examples from Israel. Hydrogeol. J. 2010, 19, 71-81. [CrossRef]

215. Shalem, Y.; Weinstein, Y.; Levi, E.; Herut, B.; Goldman, M.; Yechieli, Y. The extent of aquifer salinization next to an estuarine river: An example from the eastern Mediterranean. Hydrogeol. J. 2015, 23, 69-79. [CrossRef]

216. Bouderbala, A. The impact of climate change on groundwater resources in coastal aquifers: Case of the alluvial aquifer of Mitidja in Algeria. Environ. Earth Sci. 2019, 78, 698. [CrossRef]

217. Urresti-Estala, B.; Jiménez-Gavilán, P.; Pérez, I.V.; Cantos, F.C. Assessment of hydrochemical trends in the highly anthropised Guadalhorce River basin (southern Spain) in terms of compliance with the European groundwater directive for 2015. Environ. Sci. Pollut. Res. 2016, 23, 15990-16005. [CrossRef] [PubMed]

218. Benhamiche, N.; Sahi, L.; Tahar, S.; Bir, H.; Madani, K.; Laignel, B. Spatial and temporal variability of groundwater quality of an Algerian aquifer: The case of Soummam Wadi. Hydrol. Sci. J. 2016, 61, 775-792. [CrossRef]

219. Geriesh, M.H.; Balke, K.-D.; El-Rayes, A.E.; Mansour, B.M. Implications of climate change on the groundwater flow regime and geochemistry of the Nile Delta, Egypt. J. Coast. Conserv. 2015, 19, 589-608. [CrossRef]

220. Giambastiani, B.M.S.; Macciocca, V.R.; Molducci, M.; Antonellini, M. Factors Affecting Water Drainage Long-Time Series in the Salinized Low-Lying Coastal Area of Ravenna (Italy). Water 2020, 12, 256. [CrossRef]

221. Paster, A.; Dagan, G.; Guttman, J. The salt-water body in the Northern part of Yarkon-Taninim aquifer: Field data analysis, conceptual model and prediction. J. Hydrol. 2006, 323, 154-167. [CrossRef]

222. Molle, F.; Gaafar, I.; El-Agha, D.E.; Rap, E. The Nile delta's water and salt balances and implications for management. Agric. Water Manag. 2018, 197, 110-121. [CrossRef]

223. Shalem, Y.; Yechieli, Y.; Herut, B.; Weinstein, Y. Aquifer Response to Estuarine Stream Dynamics. Water 2019, 11, 1678. [CrossRef]

224. Mastrocicco, M.; Busico, G.; Colombani, N.; Vigliotti, M.; Ruberti, D. Modelling Actual and Future Seawater Intrusion in the Variconi Coastal Wetland (Italy) Due to Climate and Landscape Changes. Water 2019, 11, 1502. [CrossRef] 
225. Colombani, N.; Osti, A.; Volta, G.; Mastrocicco, M. Impact of Climate Change on Salinization of Coastal Water Resources. Water Resour. Manag. 2016, 30, 2483-2496. [CrossRef]

226. Mabrouk, M.; Jonoski, A.; Essink, G.O.; Uhlenbrook, S. Impacts of Sea Level Rise and Groundwater Extraction Scenarios on Fresh Groundwater Resources in the Nile Delta Governorates, Egypt. Water 2018, 10, 1690. [CrossRef]

227. Carneiro, J.F.; Boughriba, M.; Correia, A.; Zarhloule, Y.; Rimi, A.; El Houadi, B. Evaluation of climate change effects in a coastal aquifer in Morocco using a density-dependent numerical model. Environ. Earth Sci. 2009, 61, 241-252. [CrossRef]

228. Abd-Elaty, I.; Sallam, G.A.; Straface, S.; Scozzari, A. Effects of climate change on the design of subsurface drainage systems in coastal aquifers in arid/semi-arid regions: Case study of the Nile delta. Sci. Total. Environ. 2019, 672, 283-295. [CrossRef] [PubMed]

229. Haj-Amor, Z.; Acharjee, T.K.; Dhaouadi, L.; Bouri, S. Impacts of climate change on irrigation water requirement of date palms under future salinity trend in coastal aquifer of Tunisian oasis. Agric. Water Manag. 2020, 228, 105843. [CrossRef]

230. Lambrakis, N.; Kallergis, G. Reaction of subsurface coastal aquifers to climate and land use changes in Greece: Modelling of groundwater refreshening patterns under natural recharge conditions. J. Hydrol. 2001, 245, 19-31. [CrossRef]

231. De Filippis, G.; Foglia, L.; Giudici, M.; Mehl, S.; Margiotta, S.; Negri, S. Seawater intrusion in karstic, coastal aquifers: Current challenges and future scenarios in the Taranto area (southern Italy). Sci. Total. Environ. 2016, 573, 1340-1351. [CrossRef]

232. Kalaoun, O.; Al Bitar, A.; Gastellu-Etchegorry, J.-P.; Jazar, M. Impact of Demographic Growth on Seawater Intrusion: Case of the Tripoli Aquifer, Lebanon. Water 2016, 8, 104. [CrossRef]

233. Seyam, M.; Alagha, J.S.; Abunama, T.; Mogheir, Y.; Affam, A.C.; Heydari, M.; Ramlawi, K. Investigation of the Influence of Excess Pumping on Groundwater Salinity in the Gaza Coastal Aquifer (Palestine) Using Three Predicted Future Scenarios. Water 2020, 12, 2218. [CrossRef]

234. Parisi, A.; Monno, V.; Fidelibus, M.D. Cascading vulnerability scenarios in the management of groundwater depletion and salinization in semi-arid areas. Int. J. Disaster Risk Reduct. 2018, 30, 292-305. [CrossRef]

235. Da Lio, C.; Tosi, L. Vulnerability to relative sea-level rise in the Po river delta (Italy). Estuar. Coast. Shelf Sci. 2019, $228,106379$. [CrossRef]

236. Benini, L.; Antonellini, M.; Laghi, M.; Mollema, P.N. Assessment of Water Resources Availability and Groundwater Salinization in Future Climate and Land use Change Scenarios: A Case Study from a Coastal Drainage Basin in Italy. Water Resour. Manag. 2015, 30, 731-745. [CrossRef]

237. Slama, F.; Gargouri-Ellouze, E.; Bouhlila, R. Impact of rainfall structure and climate change on soil and groundwater salinization. Clim. Chang. 2020, 163, 395-413. [CrossRef]

238. Sušnik, J.; Vamvakeridou-Lyroudia, L.S.; Baumert, N.; Kloos, J.; Renaud, F.G.; La Jeunesse, I.; Mabrouk, B.; Savic, D.; Kapelan, Z.; Ludwig, R.; et al. Interdisciplinary assessment of sea-level rise and climate change impacts on the lower Nile delta, Egypt. Sci. Total. Environ. 2015, 503, 279-288. [CrossRef] [PubMed] 